\title{
Palynological Correlation of Atokan and Lower Desmoinesian (Pennsylvanian) Strata Between the Illinois Basin and the Forest City Basin in Eastern Kansas
}

\author{
Russel A. Peppers, Illinois Geological Survey, Emeritus, Champaign, IL 61820, and \\ Lawrence L. Brady, Kansas Geological Survey, Lawrence, KS 66047
}

\begin{abstract}
Palynological correlation is made between Atokan and lower Desmoinesian strata in the Illinois basin and the Forest City basin in eastern Kansas. Spore data from previous studies of coals in the Illinois basin and other coal basins are compared with data from spore assemblages in coal and carbonaceous shale bands in a core drilled in Leavenworth County, Kansas. Correlations are based on first and/or last occurrences of 31 species common to the Illinois basin and eastern Kansas and on significant increases or decreases in abundance of several of those taxa. The oldest coal, which is $26 \mathrm{ft}(8 \mathrm{~m})$ above the top of the Mississippian, is early Atokan (early Westphalian B) in age and is approximately equivalent to the Bell coal bed in the Illinois basin. The Riverton coal bed at the top of the studied interval in Kansas is early Desmoinesian (early Westphalian D) and correlates with about the Lewisport coal bed in the Illinois basin. Three coal beds near the base of the Pennsylvanian in three cores drilled in Cherokee County, Kansas, which were also studied, range in age from late Atokan to early Desmoinesian.

As in other coal basins, Lycospora, borne by lycopod trees, greatly dominates the lower and middle Atokan spore assemblages in coals and shale, but spores from ferns, especially tree ferns, significantly increase in abundance in the upper Atokan and lower Desmoinesian. The pattern of change of dominance among Lycospora pellucida, L. granulata, and L. micropapillata in middle Atokan (Westphalian B-C transition) that has been demonstrated earlier in the Illinois basin and eastern Kentucky and Tennessee, also occurs in eastern Kansas. At least 10 species of spores, which appeared in the middle Atokan in other parts of the equatorial coal belt, also appeared at this time in eastern Kansas. Most of these species have their affinities with the ferns, which were adapted to drier habitats than lycopods. Thus, the climate may have become a little drier in the equatorial coal belt during middle Atokan.
\end{abstract}

\section{Introduction}

Palynological correlation and zonation of Atokan strata in the western part of the midcontinent has not been adequately accomplished because of scarcity of Atokan coals and carbonaceous rocks in that region. Palynological correlation of subsurface Morrowan and Atokan rocks in the Forest City basin in northwestern Missouri with equivalent rocks in the Illinois basin, however, was recently carried out (Peppers et al., 1993). That 1993 study, a preliminary version of this Kansas study (Peppers and Brady, 1997), and the present study extend the earlier palynological correlation and spore zonation of the lower part of the Pennsylvanian and Middle Carboniferous from Europe, the Appalachian coal region and the Illinois basin (Peppers, 1984, 1996) to the midcontinent. Coal and carbonaceous shale samples from Atokan and lower Desmoinesian strata in four deep cores drilled in eastern Kansas were made available by the Kansas Geological Survey.

One of the purposes of this study is to provide a correlation of the lower part of the Pennsylvanian between the Illinois basin and eastern Kansas and to extend the Spore Assemblage Zones of the Illinois basin to the midcontinent. The Kansas cores contain coal beds just above the base of the Pennsylvanian; therefore, another purpose of the study was to find the age of the oldest Pennsylvanian strata in the Kansas portion of the Forest City basin. We also wanted to learn whether the pattern of changing dominance of Lycospora species in the middle Atokan that occurs in the Illinois basin and the Appalachian coal region was duplicated as far west as Kansas. The Riverton coal bed is present in all of the cores that were studied. Because there has been some question concerning the specific age of that coal, another purpose of the investigation is to determine the position of the Riverton coal in relation to the Atokan-Desmoinesian boundary. It should be noted that the U.S. Geological Survey, Kansas Geological Survey, and Oklahoma Geological Survey refer to coals as coal beds, while the Illinois Geological Survey considers major coals as members; therefore, the coal names listed in that state are upper case.

\section{Palynological Correlations in the Midcontinent}

Most of the coals in the midcontinent region that have been palynologically investigated are Desmoinesian in age because they are the most extensive and are of most economic importance. Wilson and Coe (1940), Wilson and Kosanke (1944), and Wilson (1958) described several new palynomorph taxa from the Desmoinesian of Iowa. Wilson and Hoffmeister (1956) and Wilson (1964) reported on palynology of the Croweburg coal bed, which correlates with the Colchester (No. 2) Coal Member in the Illinois basin. Palynology of the coals in the Cabaniss Group in Oklahoma and equivalent rocks in Kansas was briefly 
outlined in order to ascertain whether spores could be used to differentiate the coal beds (Wilson and Hoffmeister, 1958).

Students of L. R. Wilson have studied palynology of a number of coal beds in Oklahoma while he was associated with the University of Oklahoma and the Oklahoma Geological Survey. The paleobotanical development and succession of spore assemblages in the coals were emphasized. Most of these theses or dissertations have not been published except for Morgan's (1955) work on the McAlester, Stigler, Rowe, and Riverton coal beds. These unpublished studies describe the palynology of the following coal beds: the Secor (Clarke, 1961), Weir-Pittsburg (Higgins, 1961; Bond, 1963), Ironpost (Gibson, 1961), Rowe (Davis, 1961), Tebo (Ruffin, 1961), Mineral (Urban, 1962), McAlester (Dempsey, 1964), Drywood (Bordeau, 1964), Drywood and Bluejacket (Urban, 1965), and Bevier (Dolly, 1965). Many of these theses attempted to correlate the coals in Oklahoma with those in the Illinois basin based mainly on Kosanke's 1950 study. Wilson (1976a) used these theses to briefly summarize the palynology of Desmoinesian coals in northeastern Oklahoma. Elsewhere, Jones (1957) in his thesis at the University of Missouri, reported on the palynology of the Bevier coal in Missouri, and Rosowitz (1982) at Wichita State University reported on the palynology of the Riverton coal in Kansas.

Several earlier palynological investigations centered on placing the Desmoinesian-Missourian boundary in the midcontinent (Wilson, 1979b, 1984; Wilson and Bennison, 1981). Pearson (1975), while at the University of Oklahoma, studied the palynology of the Seminole coals in Oklahoma, which are early Missourian in age. Simpson (1969) at the University of Tulsa also wrote his thesis on the palynology of some Missourian strata in Tulsa County, Oklahoma.

Several studies of Early Pennsylvanian palynomorphs in the western part of the midcontinent also have been made. Felix and Burbridge (1967) described spores in the Springer Formation in Oklahoma, which is transitional between Mississippian and Pennsylvanian. Owens et al. (1984) and Loboziak et al. (1984) reported on spores in Mississippian and Lower Pennsylvanian strata in northern Arkansas and correlated the assemblages with those in Europe. Peppers (1996) described the spore content of the Baldwin coal bed, which is in the Bloyd Formation. Wilson (1965) reported on a spore assemblage from shale overlying the Springer Formation at Ti Valley, Pittsburg County, Oklahoma. He determined that the assemblage is Morrowan in age but that the assemblage contained recycled late Mississippian spores. Palynology of some Morrowan coal beds in eastern Iowa, which are within a westward extension of the Illinois basin, were studied by Ravn and Fitzgerald (1982).

Earliest reference to the rocks comprising the Cherokee Group in Kansas was by Haworth and Kirk (1894), who named the unit Cherokee shales for the Cherokee County, Kansas, area. The Des Moines Series in Kansas includes the lower part of the Pennsylvanian System, from an unconformity at its base to an unconformity at the base or within the Pleasanton shale (Moore, 1936, p. 51). Further defining the Des Moines series in Kansas and surrounding states, Moore (1936) states, “The lower boundary of the Des Moines series is sharply defined. North of the Kansas-Oklahoma line strata of Morrow age, which represent a part of Pennsylvanian time that is older than Des Moines, are absent. Except locally, beds of Late Mississippian (Chester) age are lacking also, and therefore the basal Des Moines rests on
Middle Mississippian limestones or it overlaps the Mississippian and is found on older Paleozoic rocks of the Ozark uplift.” Moore et al. (1944) designated Des Moines as the Desmoinesian Series for a major Pennsylvanian time-rock division in the midcontinent, and Moore, Frye, and Jewett (1944) recognized Desmoinesian Series in Kansas.

The name "Atokan” as a series was suggested by Spivey and Roberts (1946), based on fusiform fusulinids in rock units in central Texas that were post-Morrow in age. Because of stratigraphic problems with existing names, the authors chose the Atokan formation of Oklahoma and elevated it to series level based on the Fusulina-Wedekindellina presence of beds overlying beds of Desmoinesian age and the presence of Fusulinella in the Atokan beds.

Agreement on Pennsylvanian stratigraphic nomenclature was determined by the geological surveys of Kansas, Missouri, Nebraska, Iowa, and Oklahoma for units northeastward from northern Oklahoma (Moore, 1948). This agreement was reached in a meeting in Lawrence, Kansas, on May 5-6, 1947, that was attended by four of the five state surveys, with Oklahoma giving its concurrence later. Rock units of Desmoinesian, Missourian, and Virgilian time-rock subdivisions were recognized, with older Pennsylvanian units of Morrowan and Atokan recognized where differentiated. Later, Moore (1949, p. 32) believed Atokan rocks to be present in eastern Kansas and in the deeper basins in the midcontinent region.

Representatives from five states (Missouri, Kansas, Oklahoma, Nebraska, and Iowa) met in Nevada, Missouri (March 31-April 1, 1953) to establish the stratigraphy of platform deposits of pre-Marmaton Desmoinesian beds that includes the Cherokee Group, including the Riverton coal and the underlying beds (Searight et al., 1953). Generally following this established terminology, Howe (1956) presented detailed studies of the Cherokee Group, and he included that group and the underlying Pennsylvanian rocks in the Desmoinesian Stage. Later, Searight and Howe (1961) included the Riverton Formation (the lowermost formation in the Cherokee Group at that time) in the Atokan Stage.

Rocks of lowermost Cherokee Group were considered Desmoinesian or possibly upper Atokan in the outcrop area of southeast Kansas. Lowermost Pennsylvanian rocks in the Forest City basin in northeast Kansas are considered to be older than Pennsylvanian rocks in the outcrop area, and are believed to be Atokan (Jewett et al., 1968, p. 23).

In northwest Missouri, the McLouth Formation that was formally named for the subsurface McLouth sandstones first described by Lee (1941) from drill cuttings in western Jefferson County, Kansas, were considered to be Atokan in age (Searight and Howe, 1961). The overlying Riverton Formation is also considered to be Atokan in age in Missouri (Searight and Howe, 1961), while rocks equivalent to the Riverton Formation of Missouri are considered to be Desmoinesian age in Kansas (Jewett et al., 1968). Brady et al. (1994, sheet 1) compared these similar lithologies and associated stratigraphic units in southeast Kansas and southwest Missouri. In the stratigraphic columns of the publication, the discrepancy of ages assigned for similar units is clearly illustrated.

Stewart (1975) stated that not much is known about the paleontology in the deeper parts of the Forest City basin, but that regional relationships support placing the oldest Pennsylvanian 
strata in the Atokan. Nodine-Zeller and Thompson (1977) reported the presence of several conodonts in black shale in a core from Cherokee County, Kansas, which indicates an Atokan (possibly early Atokan) age. In the same report Wilson (personal communication) thought that spores from the same shale are also Atokan (or Morrowan) in age. Wilson (1976b) concluded that his study of the Atoka Formation at its type section in Oklahoma and in other areas indicates that the palynomorph assemblages are nearly identical with those in the Hartshorne Formation and are Desmoinesian in age. His conclusions, however, were based largely on spore genera, whose ranges overlap the Desmoinesian and Atokan. Rashid (1968) and Wilson and Rashid (1982) found that the spore assemblage in the Bostwick Member in southern Oklahoma, which was thought to be Atokan in age, is actually Desmoinesian. The Atokan had been cut out by erosion before deposition of the Desmoinesian (Clopine, 1991).

Ravn (1979) reported in detail on the palynology of the Blackoak Coal Member in Iowa, which is just below the AtokanDesmoinesian boundary. Ravn (1986) also described the palynomorph composition of Morrowan to Missourian coal beds in Iowa and correlated the coals with those in the Illinois basin. The Atokan in Iowa includes the Kilbourn Formation, which contains several unnamed coal beds, and the overlying Kalo Formation containing the Blackoak Coal.

\section{The Riverton Formation and Riverton Coal Bed}

The Riverton coal is an important coal in eastern Kansas, western Missouri, and northeastern Oklahoma, but geologists working in the various states have not always agreed concerning its stratigraphic position in relation to the Atokan-Desmoinesian boundary. Pierce and Courtier (1937) named the Riverton coal for a thin coal exposed in a sinkhole in Cherokee County, Kansas. Abernathy (1937) used the name Riverton Cyclothem Formation for the lowermost Pennsylvanian rocks in the area and included the Riverton coal at the top. Searight et al. (1953) in describing the Riverton Formation included the Desmoinesian rocks below the Riverton coal and Warner Sandstone. The Desmoinesian Series, which was defined in Iowa, was to include all the lower Pennsylvanian rocks (Keyes, 1896). It is now known that the lower part of the Desmoinesian in Iowa includes Atokan and Morrowan rocks (Ravn et al., 1984; Ravn, 1986). The upper part of the Riverton Formation contains one to several coals in addition to the Riverton coal. Kansas continues to recognize the Riverton coal as a bed in the Krebs Formation of the Cherokee Group (Jewett et al., 1968).

Searight et al. (1953), Searight (1955), and Howe (1956) considered the Riverton Formation in Missouri to be Desmoinesian in age, but they placed the Riverton coal and the rest of the Krebs Formation below the Seville Limestone member, which in Illinois is at the Atokan-Desmoinesian boundary. Searight and Howe (1961) transferred the Riverton Formation from the Desmoinesian to the Atokan. Atokan fusulinids were found in a limestone in the Riverton Formation in southwestern Missouri (M. L. Thompson, 1953), and Searight (1959) suggested that a limestone in the upper part of the Riverton Formation in the Forest City basin in Missouri indicated the presence of Atokan rocks. Also a sinkhole in southwestern Missouri contains Atokan conodonts in rocks thought to belong to the Riverton Formation (T. L. Thompson, 1979; Lambert and Thompson, 1990). T. L. Thompson (1979) considered the entire formation Atokan in age.

Wanless (1956) correlated the Riverton Formation in Missouri with the Caseyville Formation in the Illinois basin, and Kosanke et al. (1960) correlated it with a position below the
Seville Limestone in Illinois. The Caseyville is now considered Morrowan in age, and the interval below the Seville Limestone is Atokan (Hopkins and Simon, 1975; Peppers, 1996). A coal bed in the upper part of what the Missouri Geological Survey considers the Riverton Formation in a strip mine in Barton County, Missouri, yielded a Desmoinesian spore assemblage (Peppers et al., 1993). In addition, a coal at the top of the Riverton Formation in the subsurface of the Forest City basin in Missouri contains a Desmoinesian spore assemblage (Peppers et al., 1993). Peppers (1996) correlated, based on palynology, the Riverton coal with the early Desmoinesian Lewisport coal bed in the Illinois basin.

In Oklahoma the McAlester Formation, which contains the Riverton coal, is considered Desmoinesian in age (Moore, 1948; Fay et al., 1979; Suneson and Hemish, 1994). Branson (1962) correlated the Riverton coal with the Upper Hartshorne coal bed, but the McAlester Formation overlies the Hartshorne Formation. Wilson (1970) studied palynology of the Upper and Lower Hartshorne coals near Wilburton, Oklahoma, and he concluded that the coals are Desmoinesian in age. Peppers came to the same conclusion after examining a sample of the Hartshorne coal from sec. 14, T. 14 N., R. 19 E., in Haskell County, Oklahoma (unpublished data, 1992).

Morgan (1955) reported on the palynology of the Riverton coal at its type section in NE sec. 9, T. 32 S., R. 25 E. [lat. 37 16’39”, long. 94 38' 10”'], Cherokee County, Kansas. He concluded that the coal is older than the McAlester coal and younger than the Hartshorne coal. The sample of the Riverton coal from the same locality that Peppers examined contains a poorly preserved spore assemblage, but the limited data support an early Desmoinesian age. Wilson (1979a) also compared spore genera present in a sample of the Riverton coal in Cherokee County with the shale samples from a well in Cherokee County. Although many of the spores in the shale were recycled or have a long stratigraphic range, he concluded that the shale is probably part of the McAlester Formation. Rosowitz (1982) correlated, by use of spores, the Riverton coal from several cores in Cherokee and Crawford counties, Kansas, with the lower Hartshorne coal of Oklahoma. 


\section{Palynological Correlation of Atokan and Lower Desmoinesian Coals Between Kansas and Illinois and Other Coal Basins}

\section{Analytical Procedure for Coals in the Forest City Basin Core}

Six coal samples from the Kansas Geological Survey Edmonds 1A core drilled in the NW SW sec. 35, T. 9 S., R. 22 E., Leavenworth County, Kansas, in the western part of the Forest City basin were palynologically analyzed. Also, one coal sample from each of three other cores drilled in Cherokee County, Kansas, were macerated and studied (fig. 1, table 1). Later, samples from seven carbonaceous shale intervals in the Kansas Geological Survey core were macerated. The samples were taken from all the carbonaceous shales in the 82-ft-thick interval in the Leavenworth County core between the coal beds of macerations 3289B and C. These sample locations of carboniferous shales and lower coals are shown on the Edmonds 1A core in the north-south profile of Cherokee Group rocks and older Pennsylvanian rocks across eastern Kansas (fig. 2).

The coal samples were macerated with Schultze's solution and $5 \% \mathrm{KOH}$ solution. Shale samples were treated with $10 \%$ $\mathrm{HCl}$ solution to dissolve carbonate minerals and then with $\mathrm{HF}$ acid to dissolve the silicate minerals. Macerated residues were centrifuged in 1.9 SG solution of zinc chloride to separate undissolved mineral matter from organic remains. Microscope slides of the spore residues were examined until no new taxa were observed on an entire slide. A count was made of 200 specimens in each maceration to determine the relative abundance of taxa in the spore assemblages.

Correlations were based on first and/or last occurrence of 31 spore species and major changes in relative abundance of several taxa. Stratigraphic ranges and relative abundance of spores in the Kansas cores were compared with their ranges and abundance in Iowa, Illinois basin, and the Missouri and Kansas portions of the Forest City basin; coal areas in the Appalachian coal region; and in Europe. Previous palynological studies of Smith and Butterworh (1967), Clayton et al. (1977), Ravn (1986), Kosanke (1988), Eble (1994), Peppers (1984, 1996) and Peppers et al. (1993) were especially useful. Some differences in chronostratigraphic ranges were expected when comparing palynologic floras in coal as well as in shale because of differences in environments of deposition. Nevertheless, no major inconsistencies in spore ranges, when compared with those in other regions were encountered.

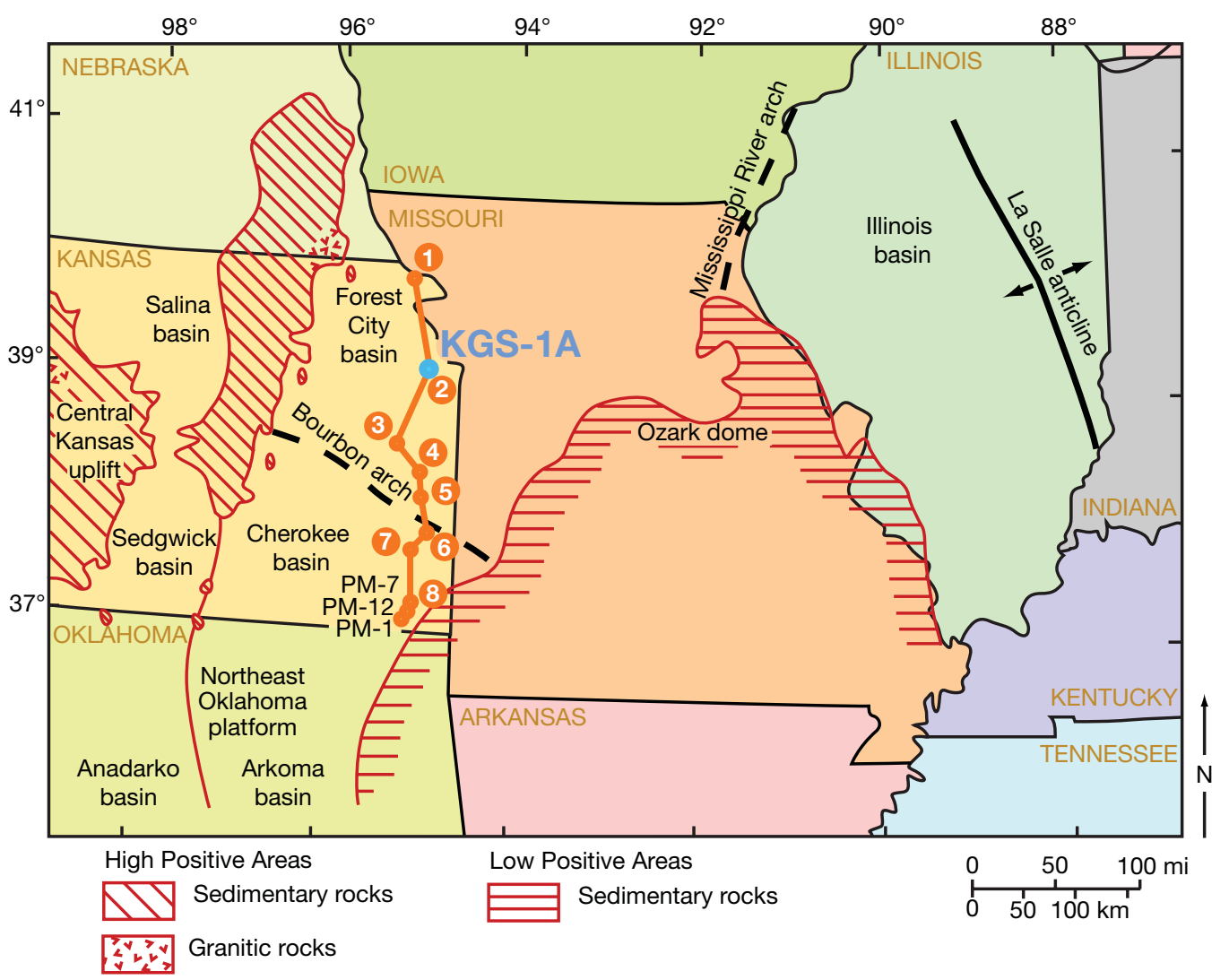

FIGURE 1-Location of wells containing coal beds and carbonaceous shale bands that were sampled and macerated for study. 1) KGS Edmonds No. 1A; 2) Gulf Oil Corp., Pittsburg \& Midway PM-1; 3) Gulf Oil Corp., Pittsburg \& Midway PM-7; 4) Gulf Oil Corp., Pittsburg \& Midway PM-12; and location of the profile of the Cherokee Group in eastern Kansas as shown in fig. 5. General figure modified from Wright (1975). 
TABLE 1-Location of wells and depths from which macerated coal samples and carbonaceous shale samples were obtained.

\begin{tabular}{|c|c|c|}
\hline Macerations & Lithology & Depth in Feet \\
\hline & \multicolumn{2}{|c|}{$\begin{array}{l}\text { Kansas Geological Survey Edmonds No. 1A: NW SW sec. 35, T.9 S., R. } 22 \text { E. } \\
\left.\text { [lat. 39 13’09”, long. } 94^{\circ} 56^{\prime} 00^{\prime}\right] \text {, Leavenworth County, Kansas }\end{array}$} \\
\hline 3289A & coal & 1164.3-1164.6 \\
\hline B & coal & 1157.5-1157.8 \\
\hline $\mathrm{C}$ & coal & 1075.2-1075.7 \\
\hline $\mathrm{D}$ & coal & 1074.7-1075.2 \\
\hline $\mathrm{E}$ & coal & 1056.4-1057.2 \\
\hline $\mathrm{F}$ & coal & 1055.3-1056.3 \\
\hline 3295A & carbonaceous shale & 1148.9-1149.0 \\
\hline B & carbonaceous shale & 1132.9 \\
\hline $\mathrm{C}$ & carbonaceous shale & 1130.4-1130.55 \\
\hline $\mathrm{D}$ & carbonaceous shale & 1129.5 \\
\hline $\mathrm{E}$ & carbonaceous shale & 1125.2 \\
\hline $\mathrm{F}$ & carbonaceous shale & 1115.7 \\
\hline \multirow[t]{2}{*}{ G } & carbonaceous shale & 1088.2 \\
\hline & \multicolumn{2}{|c|}{$\begin{array}{l}\text { Gulf Oil Corp., Pittsburg-Midway PM-1: NE NW sec. 13, T. } 33 \text { S., R. } 21 \text { E. } \\
\text { [lat. } 37^{\circ} 10^{\prime} 42^{\prime}, \text { long. } 94^{\circ} \text { 57’ 12”], Cherokee County, Kansas }\end{array}$} \\
\hline \multirow[t]{2}{*}{3286} & coal & 389.9-390.5 \\
\hline & \multicolumn{2}{|c|}{$\begin{array}{l}\text { Gulf Oil Corp., Pittsburg-Midway PM-7: SW SE sec. 6, T. } 32 \text { S., R. } 22 \text { E. } \\
\text { [37 16’ 57”, long. 95 16’ 57’], Cherokee County, Kansas }\end{array}$} \\
\hline \multirow[t]{2}{*}{3287} & coal & 449.6-450.0 \\
\hline & \multicolumn{2}{|c|}{$\begin{array}{l}\text { Gulf Oil Corp., Pittsburg-Midway PM-12: SW NE sec. 19, T. } 32 \text { S., R. } 22 \text { E. } \\
\text { [lat. } 37^{\circ} 14^{\prime} \text { 55”, long. 95 92’ 20”], Cherokee County, Kansas }\end{array}$} \\
\hline 3288 & coal & 435.7-437.3 \\
\hline
\end{tabular}

The three Gulf cores and the KGS core are stored at the core facility of the Kansas Geological Survey, Lawrence, Kansas.

\section{Palynological Study of Atokan and Lower Desmoinesian Coals and Carbonaceous Shales in the Forest City Basin Core}

The coal between 1,164.3 and 1,164.6 ft (354.9-355 m) (maceration 3289A — summarized in table 2) in the Kansas Geological Survey Edmonds 1A core (Leavenworth County, Kansas) is $30 \mathrm{ft}(9 \mathrm{~m})$ above the base of the Pennsylvanian. It is early Atokan (early Westphalian B) in age and correlates approximately with the Bell coal bed in the Illinois basin (fig. 3). This coal correlates with the lower part of the Microreticulatisporites nobilis-Endosporites globiformis (NG) Spore Assemblage Zone in the Illinois basin (Peppers, 1984). Schulzospora rara, which is an index spore for the Lower Pennsylvanian (midcontinent usage), was not observed in the coal. The species extends to the top of the Morrowan in the Illinois basin (Peppers, 1984), the top of the "McLouth Sandstone" in the Missouri part of the Forest City basin (Peppers et al., 1993), the lower part of the Middle Pennsylvanian in the Appalachian region (Kosanke, 1988) (NOTE: U.S. Geological Survey usage places the Lower-Middle Pennsylvanian boundary lower in this area than where they place it in the midcontinent), and the top of the Westphalian A in Europe (Clayton et al., 1977). Sinuspores sinuatus and Waltzispora prisca occur in maceration 3289A (table 2) and extend up to a little above the Bell coal bed in the Illinois basin (Peppers, 1996). Both species occur in an unnamed formation in the lower part of the Atokan in the Forest City basin in northwestern Missouri (Peppers et al., 1993). Sinuspores sinuatus was recorded in the Caseyville Formation and lower part of the Atokan Kilbourn Formation in Iowa (Ravn, 1986). Kosanke (1988) reported Punctatisporites sinuatus (=Sinuspores sinuatus) as extending up to the Hernshaw coal bed (now called Fireclay coal) in the middle of the Kanawha Formation (upper Westphalian B) in West Virginia. The species disappears at the top of Westphalian A (Smith and Butterworth, 1967) to lower Westphalian B (Coquel, 1976) in Europe. 


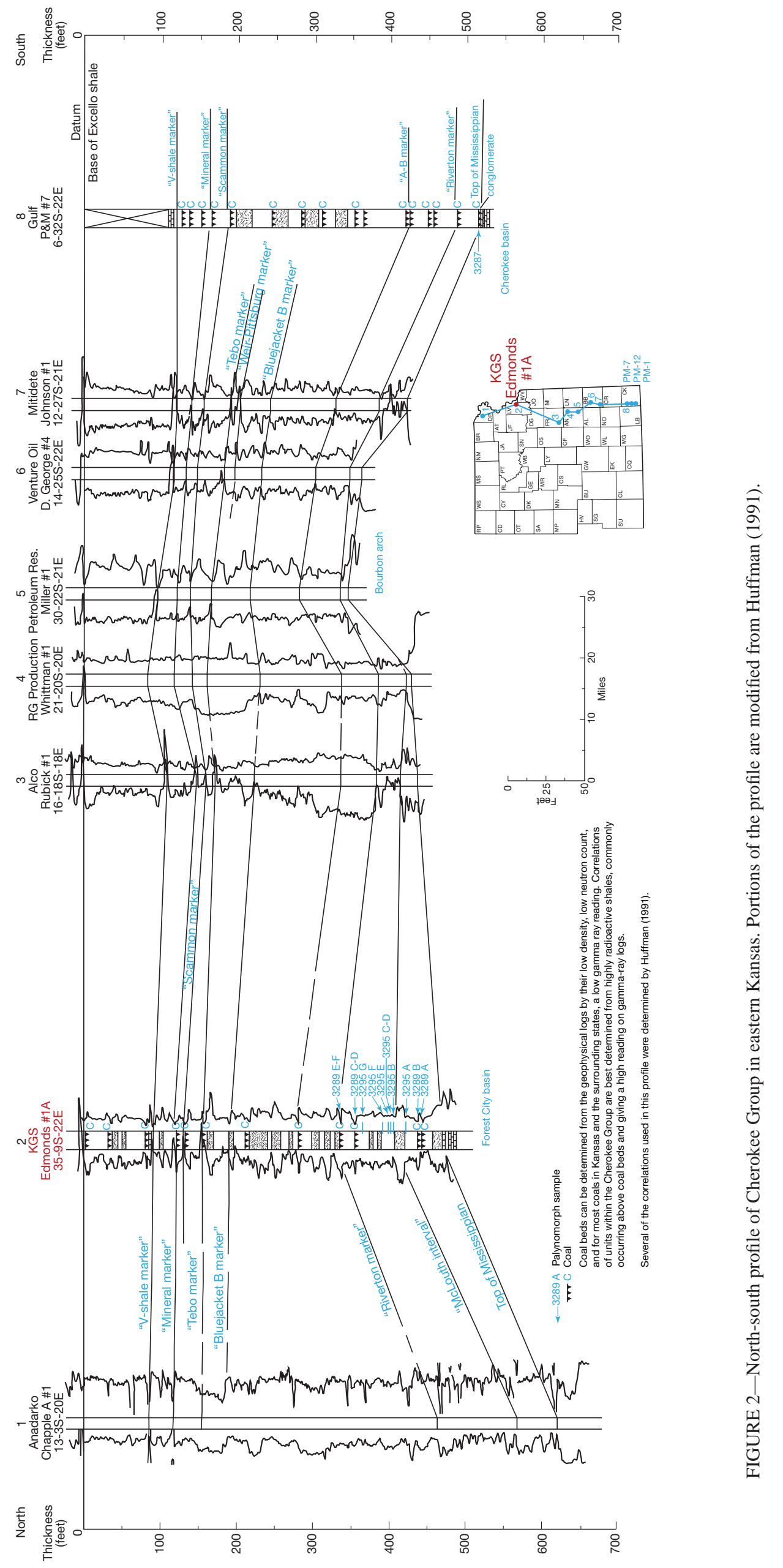

Current Research in Earth Sciences, Bulletin 253, part 1 (http://www.kgs.ku.edu/Current/2007/Peppers/index.html 


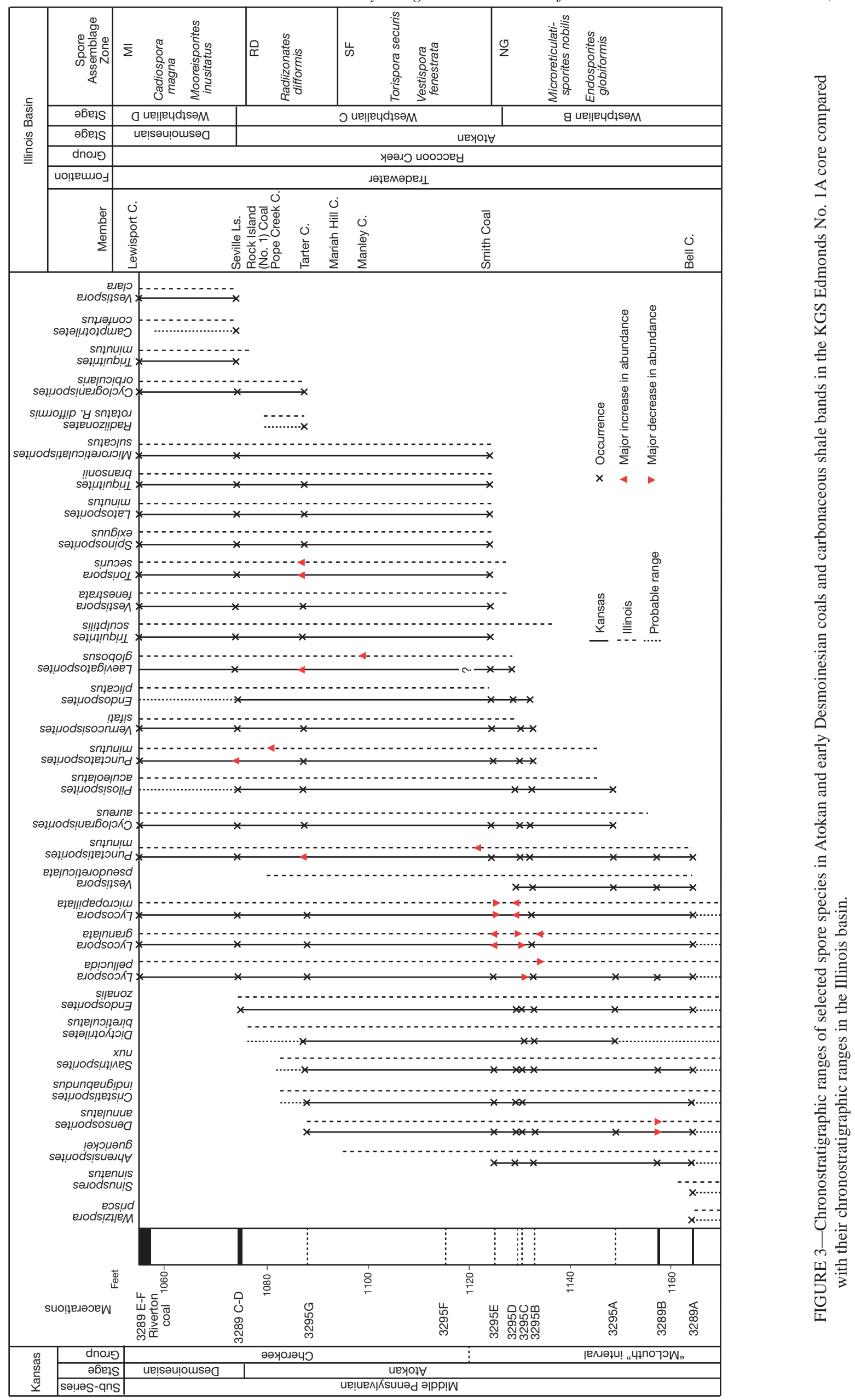

Current Research in Earth Sciences, Bulletin 253, part 1 (http://www.kgs.ku.edu/Current/2007/Peppers/index.html 
TABLE 2-Palynology of Atokan and early Desmoinesian coal beds and carbonaceous shale bands in the KGS Edmonds No. 1A core from Leavenworth County, Kansas. Numbers are percent of taxon in the spore assemblage, and " $\mathrm{X}$ ” indicates taxon present but not observed in spore count.

\begin{tabular}{|c|c|c|c|c|c|c|c|c|c|c|c|c|}
\hline & \multicolumn{2}{|c|}{3289} & \multicolumn{5}{|c|}{3295} & \multirow[b]{2}{*}{ G } & \multicolumn{4}{|c|}{3289} \\
\hline & A & B & A & B & $\mathrm{C}$ & D & $\mathbf{E}$ & & C & D & $\mathbf{E}$ & $\mathbf{F}$ \\
\hline Deltoidospora adnata & & & 0.5 & & & & $\mathrm{X}$ & 0.5 & & 0.5 & & \\
\hline D. priddyi & & & & $\mathrm{X}$ & 1.5 & $\mathrm{X}$ & $\mathrm{X}$ & & $\mathrm{X}$ & $\mathrm{X}$ & & 1.0 \\
\hline D. pseudolevis & & & & & & $\mathrm{X}$ & $\mathrm{X}$ & & $\mathrm{X}$ & & $\mathrm{X}$ & \\
\hline D. sphaerotriangula & & $\mathrm{X}$ & $\mathrm{X}$ & & $\mathrm{X}$ & $\mathrm{X}$ & & $\mathrm{X}$ & & & & \\
\hline D. subintorta & & $\mathrm{X}$ & & & & & & & & & & \\
\hline D. sp. & & 0.5 & $\mathrm{X}$ & & & & & 0.5 & & & & 0.5 \\
\hline Punctatisporites edgarensis & & & & $\mathrm{X}$ & & & & & & & & \\
\hline P. cf. edgarensis & & & & $\mathrm{X}$ & & & & & & & & \\
\hline P. flavus & & & & & & & & 0.5 & $\mathrm{X}$ & 1.5 & $\mathrm{X}$ & \\
\hline P. glaber & & 1.0 & $\mathrm{X}$ & $\mathrm{X}$ & & $\mathrm{X}$ & 1.0 & $\mathrm{X}$ & & $\mathrm{X}$ & $\mathrm{X}$ & $\mathrm{X}$ \\
\hline P. incomptus & & & & & $\mathrm{X}$ & & & & & & & \\
\hline P. minutus & & & & $\mathrm{X}$ & $\mathrm{X}$ & & $\mathrm{X}$ & 1.0 & 18.0 & 3.0 & 4.0 & 0.5 \\
\hline P. obesus & $\mathrm{X}$ & & $\mathrm{X}$ & & & & $\mathrm{X}$ & $\mathrm{X}$ & $\mathrm{X}$ & & & \\
\hline P. sp. & & & & & & 0.5 & & & & & & \\
\hline Calamospora breviradiata & 0.5 & 0.5 & & & & $\mathrm{X}$ & $\mathrm{X}$ & 0.5 & 1.5 & 1.0 & & $\mathrm{X}$ \\
\hline C. hartungiana & 1.0 & 1.5 & 0.5 & 0.5 & $\mathrm{X}$ & $\mathrm{X}$ & 0.5 & & 1.5 & & 1.0 & $\mathrm{X}$ \\
\hline C. liquida & & & $\mathrm{X}$ & & & & & & & & & \\
\hline C. mutabilis & & & & & $\mathrm{X}$ & & & & & & & \\
\hline C. straminea & & & $\mathrm{X}$ & & & & & & & & & $\mathrm{X}$ \\
\hline C. sp. & & & & & & & 1.0 & & 0.5 & & & 0.5 \\
\hline Adelisporites multiplicatus & & & & & & & 0.5 & & & & & \\
\hline Granulatisporites granularis & & 1.0 & 1.0 & & & $\mathrm{X}$ & $\mathrm{X}$ & & & & & \\
\hline G. microgranifer & 0.5 & & & 0.5 & & $\mathrm{X}$ & $\mathrm{X}$ & & & & & \\
\hline G. minutus & 0.5 & $\mathrm{X}$ & 1.5 & & 1.5 & 0.5 & & 1.5 & 1.0 & & 1.0 & 1.0 \\
\hline G. pallidus & 1.0 & & & & & & & 1.0 & & 0.5 & 0.5 & $\mathrm{X}$ \\
\hline G. verrucosus & 0.5 & & $\mathrm{X}$ & & & & & & & & & \\
\hline G. sp. & & $\mathrm{X}$ & & & 3.5 & & 0.5 & 0.5 & 0.5 & & & \\
\hline Cyclogranisporites aureus & & & 0.5 & $\mathrm{X}$ & & 1.0 & 0.5 & 0.5 & $\mathrm{X}$ & $\mathrm{X}$ & 1.0 & $\mathrm{X}$ \\
\hline C. leopoldi & & & $\mathrm{X}$ & & & & & 0.5 & & & & \\
\hline C. microgranus & & & & & & & & $\mathrm{X}$ & 2.0 & & & \\
\hline C. minutus & & & & & & & & & $\mathrm{X}$ & & & \\
\hline C. obliquus & & & & & & & & & 2.0 & & 4.0 & 2.5 \\
\hline C. orbicularis & & & & & & & & 3.0 & $\mathrm{X}$ & & 0.5 & \\
\hline Cyclogranisporites staplinii & & & & & & & & $\mathrm{X}$ & & & & \\
\hline C. sp. & & & & 0.5 & & $\mathrm{X}$ & & & 0.5 & & 0.5 & 0.5 \\
\hline Sinuspores sinuatus & $\mathrm{X}$ & & & & & & & & & & & \\
\hline Converrucosisporites armatus & & & & $\mathrm{X}$ & & & 0.5 & & & & & \\
\hline C. sp. & & & & & & & & $\mathrm{X}$ & & & & \\
\hline $\begin{array}{l}\text { Verrucosisporites } \\
\text { microtuberosus }\end{array}$ & & $\mathrm{X}$ & & $\mathrm{X}$ & $\mathrm{X}$ & $\mathrm{X}$ & $\mathrm{X}$ & & & 0.5 & & \\
\hline V. sifati & & & & $\mathrm{X}$ & & & $\mathrm{X}$ & $\mathrm{X}$ & $\mathrm{X}$ & 0.5 & & $\mathrm{X}$ \\
\hline V. verrucosus & & & & & & & & $\mathrm{X}$ & $\mathrm{X}$ & $\mathrm{X}$ & & \\
\hline V. cf. verrucosus & & & & & & & & $\mathrm{X}$ & & & & \\
\hline V. sp. & & & $\mathrm{X}$ & & & & & & & & & $\mathrm{X}$ \\
\hline
\end{tabular}

Current Research in Earth Sciences, Bulletin 253, part 1 (http://www.kgs.ku.edu/Current/2007/Peppers/index.html 


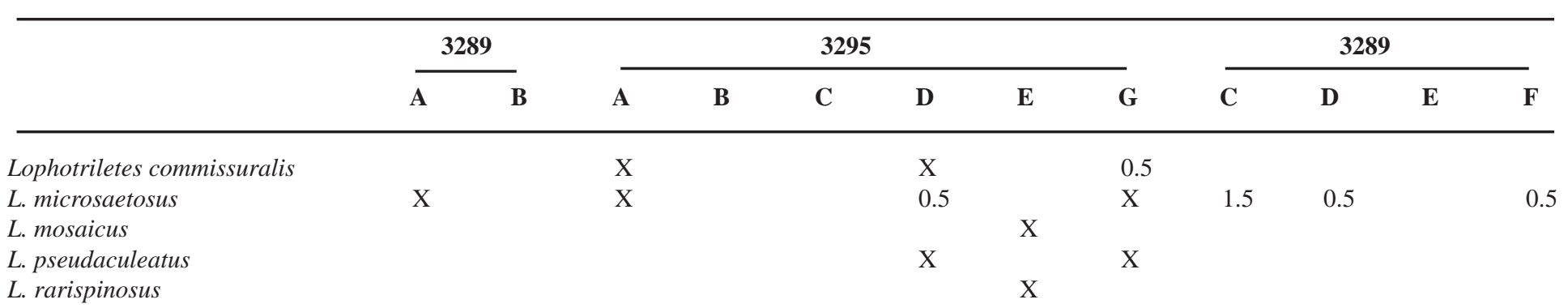

Waltzispora prisca

Anapiculatisporites spinosus

Pustulatisporites crenatus

P. sp.

Apiculatasporites latigranifer

A. setulosus

A. spinososaetosus

A. variocorneus

Planisporites granifer

Pilosisporites aculeolatus

P. williamsii

Echinatisporis knoxiae

Raistrickia abdita

R. aculeata

R. aculeolata

$R$. breviminens

R. crocea

Spackmanites habibii

Convolutispora florida

C. sp.

Microreticulatisporites

concavus

M. nobilis

M. sulcatus

Dictyotriletes bireticulatus

Camptotriletes bucculentus

C. confertus

Ahrensisporites guerickei var. ornatus

Trilobates bellii

Triquitrites additus

T. bransonii

T. exiguus

T. minutus

T. sculptilis

T. tribullatus

T. sp.

Zosterosporites triangularis
X

X

0.5

0.5

X

$\mathrm{X}$

$\mathrm{X}$

0.5

X X

X

X

0.5

$\begin{array}{llllll}\mathrm{X} & \mathrm{X} & \mathrm{X} & & 0.5 & \mathrm{X} \\ \mathrm{X} & 1.0 & & \mathrm{X} & & \\ & & & & \end{array}$

0.5

$1.0 \quad \mathrm{X}$

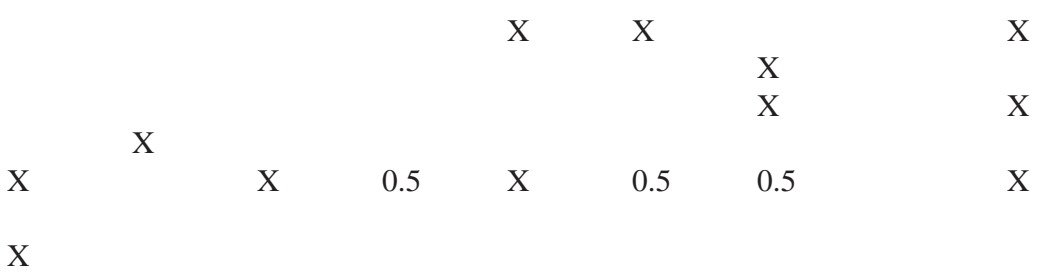

$\mathrm{X}$

X $\quad$ X

X X

X

X

X

$\mathrm{X}$

X

0.5
$X$

1.5

X

$\begin{array}{lll}0.5 & 0.5 & 0.5\end{array}$

X

$\begin{array}{llllll}2.0 & 2.5 & 1.0 & 0.5 & 0.5 & 0.5\end{array}$

X X

$0.5 \quad 0.5$

0.5

X

\begin{tabular}{|c|c|c|c|c|c|c|}
\hline & & $X$ & $X$ & & 0.5 & \\
\hline \multirow[t]{3}{*}{$\mathrm{X}$} & & 2.0 & 3.0 & 0.5 & 2.5 & $\mathrm{X}$ \\
\hline & & X & 1.5 & & X & $X$ \\
\hline & & & $X$ & & $X$ & \\
\hline$X$ & $X$ & 0.5 & 2.0 & $X$ & 4.0 & 0.5 \\
\hline
\end{tabular}

$\begin{array}{lllll}X & X & X & X\end{array}$ 


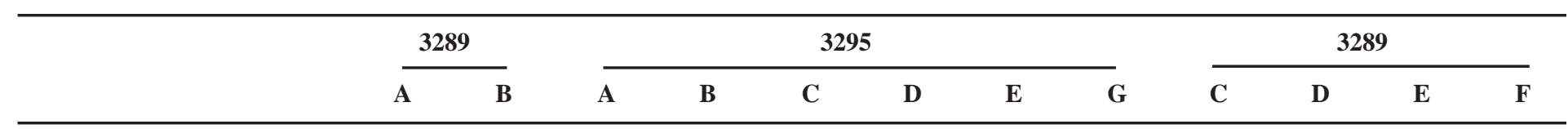

Mooreisporites sp.

Reinschospora magnifica

R. speciosa

Knoxisporites triradiatus

Reticulatisporites

mediareticulatus

R. muricatus

$R$. polygonalis

$R$. reticulatus

Reticulitriletes clatriformis

Savitrisporites concavus

S. nux

Grumosisporites

varioreticulatus

Crassispora kosankei

Granasporites medius

Simozonotriletes intortus

Densosporites annulatus

D. irregularis

D. regalis

D. sphaerotriangularis

D. triangularis

Lycospora granulata

L. micropapillata

L. pellucida

L. rotunda

Cristatisporites connexus

C. indignabundus

Cirratriradites annuliformis

C. saturnii

C. sp.

Radiizonates rotatus

Endosporites globiformis

E. plicatus

E. staplinii

E. zonalis

Paleospora fragila

Alatisporites hexalatus

A. pustulatus

A. trialatus

Laevigatosporites

desmoinesensis

L. globosus

L. medius
$\mathrm{X}$

$\begin{array}{ll} & \mathrm{X} \\ \mathrm{X} & \mathrm{X}\end{array}$

X

X

X

0.5

X

$\mathrm{X}$
$\mathrm{X}$

X

X

$\mathrm{X}$

X

X

X

X

X 1.5

$\begin{array}{lll}\text { X } & \text { X } & 0.5\end{array}$

$\mathrm{X} \quad \mathrm{X} \quad \mathrm{X}$

X

0.5

0.5

$\mathrm{X} \quad \mathrm{X} \quad \mathrm{X}$

$\begin{array}{llllllll}17.0 & 15.0 & 2.0 & \mathrm{X} & 1.0 & 1.5 & 2.5 & 1.0\end{array}$

X

0.5

11.0

$\begin{array}{ll}45.0 & 18.5 \\ 7.0 & \mathrm{X}\end{array}$

14.5

$9.0 \quad 1.0$

1.0
$X$

19.0

25.0

$20.0 \quad 1.0 \quad 32.0$

$\begin{array}{lll}1.0 & 0.5 & 2.0\end{array}$

37.5

31.5

35.0

$\begin{array}{ll}1.0 & 32.0 \\ & 1.5\end{array}$

35.0

2.0

$\begin{array}{ll}17.0 & 13.0\end{array}$

16.5

$24.0 \quad 29.5$

$18.5 \quad 1.5$

$\begin{array}{ll}17.0 & 7.0 \\ 3.5 & 2.0\end{array}$

$3.5 \quad 2.0$

1.5

11.0

10.5

7.0

7.5

9.5

5.5

0.5

0.5

$1.5 \quad 7.0$

$\begin{array}{rl} & X \\ 2.0 & X\end{array}$

$\mathrm{X}$

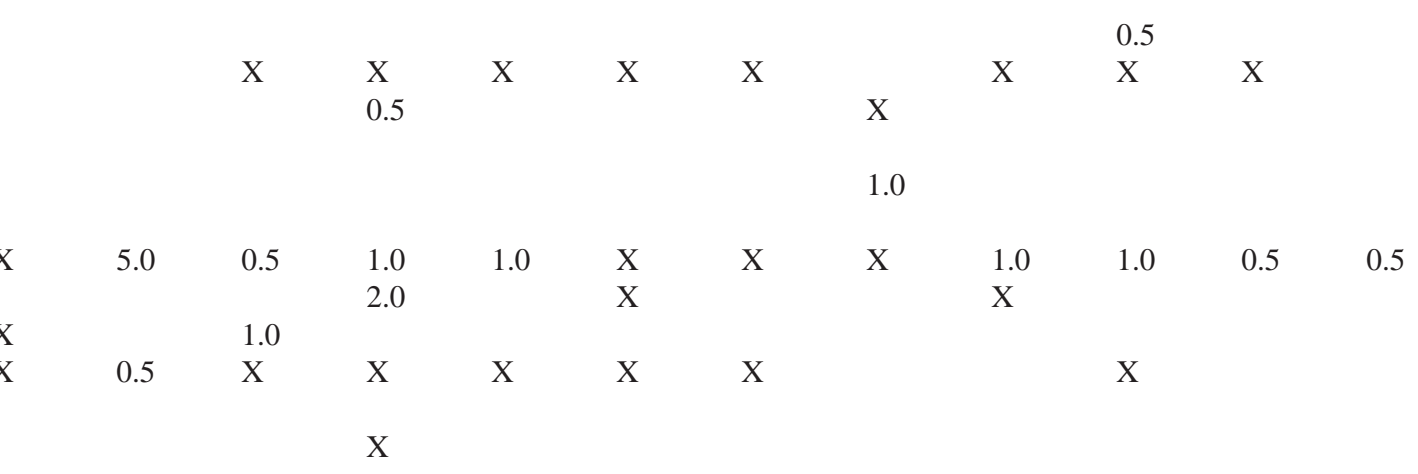

$0.5 \mathrm{X}$

16.5

$2.0 \quad 0.5$

0.5

1.0

0.5

X

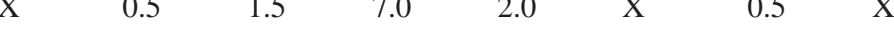

X

X

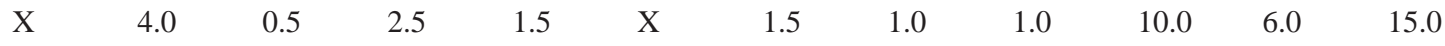

$\begin{array}{llllll}\mathrm{X} & \mathrm{X} & 7.0 & 7.0 & 3.0 & 5.5\end{array}$

$\mathrm{X} \quad 1.0 \quad \mathrm{X} \quad 1.0$ 


\begin{tabular}{|c|c|c|c|c|c|c|c|c|c|c|c|c|}
\hline & \multicolumn{2}{|c|}{3289} & \multicolumn{5}{|c|}{3295} & & \multicolumn{4}{|c|}{3289} \\
\hline & A & B & A & B & C & D & $\mathbf{E}$ & G & C & D & $\mathbf{E}$ & $\mathbf{F}$ \\
\hline L. ovalis & 2.5 & 1.5 & 0.5 & 0.5 & 1.5 & 0.5 & 2.0 & 5.0 & 3.5 & 5.0 & 7.5 & 8.5 \\
\hline L. vulgaris & $\mathrm{X}$ & $\mathrm{X}$ & & $\mathrm{X}$ & & & $\mathrm{X}$ & 1.0 & 0.5 & & $\mathrm{X}$ & $\mathrm{X}$ \\
\hline Latosporites minutus & & & & & & & 0.5 & 1.0 & 8.5 & 1.5 & 0.5 & 2.5 \\
\hline Punctatosporites minutus & 0.5 & $\mathrm{X}$ & 2.0 & $\mathrm{X}$ & 2.5 & & 0.5 & 8.0 & 3.5 & 5.0 & & 1.5 \\
\hline Spinosporites exiguus & & & & & & & & 0.5 & 1.0 & 0.5 & 1.0 & 1.0 \\
\hline Dictyomonolites swadei & & & & & & $\mathrm{X}$ & & & & & & \\
\hline Torispora securis & & & & & & & $\mathrm{X}$ & 4.5 & 12.0 & 1.5 & 10.5 & 3.5 \\
\hline Vestispora clara & & & & & & & & & $\mathrm{X}$ & & $\mathrm{X}$ & \\
\hline V. fenestrata & & & & & & & $\mathrm{X}$ & $\mathrm{X}$ & & $\mathrm{X}$ & $\mathrm{X}$ & 0.5 \\
\hline V. foveata & & & & & & & & & & & $\mathrm{X}$ & \\
\hline V. pseudoreticulata & 0.5 & $\mathrm{X}$ & $\mathrm{X}$ & $\mathrm{X}$ & & $\mathrm{X}$ & & & & & & \\
\hline $\begin{array}{l}\text { Florinites mediapudens } \\
\text { F. millottii }\end{array}$ & 2.0 & 0.5 & 8.0 & 0.5 & 8.0 & $\begin{array}{l}1.0 \\
X\end{array}$ & 6.0 & 12.0 & $\begin{array}{l}4.0 \\
\mathrm{X}\end{array}$ & 7.0 & 7.0 & 2.5 \\
\hline F. similis & $\mathrm{X}$ & & $\mathrm{X}$ & & 1.5 & $\mathrm{X}$ & 0.5 & 0.5 & & & & \\
\hline F. visendus & 0.5 & & & & & & & $\mathrm{X}$ & & & & \\
\hline F. volans & & $\mathrm{X}$ & & & & $\mathrm{X}$ & & 0.5 & & & & \\
\hline Wilsonites delicatus & & & $\mathrm{X}$ & & & & $\mathrm{X}$ & & & & & \\
\hline W. vesicatus & & & & 0.5 & $\mathrm{X}$ & 0.5 & 0.5 & 1.0 & $\mathrm{X}$ & & & \\
\hline Quasillinites diversiformis & $\mathrm{X}$ & $\mathrm{X}$ & $\mathrm{X}$ & & & & & $\mathrm{X}$ & & & & \\
\hline Peppersites ellipticus & & & & $\mathrm{X}$ & & & & $\mathrm{X}$ & & & & \\
\hline Botryococcus braunii & & & & & & & $\mathrm{X}$ & $\mathrm{X}$ & & & & \\
\hline Trihyphaecites triangulatus & & & & & & $\mathrm{X}$ & & & & & & \\
\hline
\end{tabular}

Punctatosporites minutus and Vestispora pseudoreticulata also occur in the oldest coal in the core, and they first appear near the bases of the Tradewater Formation and Atokan Stage in Illinois. Vestispora pseudoreticulata occurs for the first time near the base of the Kilbourn Formation in Iowa (Ravn, 1986) and in the lower Atokan in the Missouri portion of the Forest City basin. It begins its range in the River Gem coal bed in eastern Kentucky and in the Coal Creek coal bed in eastern Tennessee, which are approximately correlative with the Bell coal in the Illinois basin (Phillips and Peppers, 1984). Punctatosporites minutus first appears in the Gilbert coal bed in the lower part of the Middle Pennsylvanian in West Virginia (Kosanke, 1988). In western Europe P. minutus and V. pseudoreticulata begin their ranges, depending on location, in the middle Westphalian A to lower Westphalian B. Maceration 3289A also contains Endosporites globiformis, which first appears at the base of the Atokan in the Illinois basin, Iowa, and the eastern part of the Forest City basin. In eastern Kentucky and Tennessee, it was first observed in the lower part of the Middle Pennsylvanian (Peppers, 1996). In West Virginia, Kosanke (1984) reported that E. globiformis appears in the Cedar Grove coal bed in the lower part of the Middle Pennsylvanian (U.S Geological Survey usage), but Eble (1996) reported it in coals in Virginia as old as Early Pennsylvanian. The range of the species begins at the Westphalian A-B boundary in Great Britain (Smith and Butterworth, 1967). Simozonotriletes intortus and Grumosisporites varioreticulatus, which became extinct in the late Atokan in the Illinois basin and Iowa, were observed in the coal sample.

The coal at $1,157.5$ to $1,157.8 \mathrm{ft}(352.8-352.9 \mathrm{~m})$ (maceration 3289B) in table 2 is only $7 \mathrm{ft}(2 \mathrm{~m})$ above the oldest coal. Except for Savitrisporites concavus, which extends into the middle Atokan in Illinois, no additional spore taxa of stratigraphic significance appear in the coal.

The carbonaceous shale band (maceration 3295A) at $1,149 \mathrm{ft}(350 \mathrm{~m})$ is correlated with the middle of the Microreticulatisporites nobilis-Endosporites globiformis (NG) Spore Assemblage Zone in the Illinois basin. Pilosisporites aculeolatus and Cyclogranisporites aureus appear for the first time. Pilosisporites aculeolatus begins its range in an unnamed coal a little below the middle of the Atokan in the Kentucky part of the Illinois basin (Peppers, 1984) and in an unnamed coal in the Kilbourn Formation of Iowa. It first appears in an unnamed lower Atokan sequence above the "McLouth Sandstone" in the Missouri portion of the Forest City basin (Peppers et al., 1993). In the Appalachian region Pilosisporites triquetrus, which is probably synonymous with $P$. aculeolatus, was first 
reported in the Powellton coal bed in the middle of the Kanawha Formation of West Virginia (Kosanke, 1988) and in the Blue Gem coal bed in Tennessee (Phillips and Peppers, 1984).

Pilosisporites triquetrus appears for the first time in Great Britain in upper Westphalian B coals (Smith and Butterworth, 1967). Cyclogranisporites aureus begins its range a little earlier (lower part of the Atokan) in the Illinois basin than in eastern Kansas. In Iowa it occurs in the lower part of the Kilbourn Formation, and in the eastern part of the Forest City basin, it was first observed in the middle of the lower half of the Atokan. Kosanke (1988) reported the first occurrence of the species in West Virginia in the Powellton Coal. Endosporites staplinii and Knoxisporites triradiatus, which disappear in the upper Atokan, were noted in maceration 3295A (table 2). Crassispora cf. kosankei, which is a large form of the species, was also observed in maceration 3295A. It occurs in the lower Atokan in the Illinois and Forest City basins.

Several important palynological events occur in the short interval between 1,125.2 and 1,132.9 ft (343-345 m) in which four thin carbonaceous shale bands occur (macerations 3295 B-E, table 2). The shales of macerations 3295 B-D are correlated with the upper part of the Microreticulatisporites nobilis-Endosporites globiformis Spore Assemblage Zone in the Illinois basin. Punctatisporites minutus, which is one of the most common spores from the lower part of the Middle Pennsylvanian through the remainder of the period, appears in maceration 3295B. Ravn (1986) reported P. minutus in Iowa coal beds as old as Morrowan in age, but the illustrated specimens (Ravn, 1986) may belong to a similar species, Cyclogranisporites minutus. Punctatisporites minutus first occurs in the lower one-third of the Atokan in Illinois and Missouri. Verrucosisporites sifati and Endosporites plicatus also appear for the first time in maceration 3295B. These two species appear just below the Smith coal bed, which is about middle Atokan in age in the Illinois basin. They appear a little earlier than the middle of Atokan in the eastern part of the Forest City basin. In Iowa, Ravn (1986) reported that $V$. sifati and E. plicatus occur near the end of the Atokan. In the Appalachian region V. sifati appears in the Coal Creek coal bed in the Slatestown Formation in Tennessee (Peppers, 1996). Endosporites plicatus appears in the upper part of the Kanawha Formation in the Appalachian region. Alatisporites pustulatus, which also occurs in maceration 3295B, begins its range just below the middle Atokan in Illinois and the Missouri part of the Forest City basin. In Iowa it begins near the base of the Atokan.

Laevigatosporites globosus was recorded for the first time in the shale band macerated as 3295D (table 2). It appears a little below middle Atokan in the Illinois basin. It occurs in the upper Atokan, which is equivalent to the Westphalian C, in Iowa (Ravn, 1986) and the eastern part of the Forest City basin. It appears in the Redoak Mountain Formation in Tennessee (Phillips et al., 1985) and in the upper part of the Kanawha Formation in West Virginia (Eble, 1994). Latosporites globosus, which is synonymous with Laevigatosporites globosus, also appears in middle Westphalian C in Great Britain (Smith and Butterworth, 1967). Vestispora pseudoreticulata becomes extinct above the shale of maceration 3295D. It extends to the top of the Atokan in the Illinois basin and up to the Stockton "A" coal bed near the base of the Charleston Sandstone in the Appalachian coal region. According to Ravn (1986), it ranges well up into the Desmoinesian in Iowa. Vestispora pseudoreticulata extends to the top of Westphalian C in Europe. Apiculatasporites variocorneus, which disappears in the upper Atokan in the Illinois basin and Iowa, was also observed in maceration 3295D.

The shale band (maceration 3295E, table 2) at 1,125.2 $\mathrm{ft}$ (343 m) is correlated with the lower part of the Torispora securis-Vestispora fenestrata (SF) Spore Assemblage Zone and middle Atokan in the Illinois basin (Peppers, 1984). Triquitrites sculptilis, T. bransonii, Spinosporites exiguus, Latosporites minutus, Microreticulatisporites sulcatus, Vestispora fenestrata, and Torispora securis appear for the first time in the shale. All but $T$. sculptilis, which appears a little below the middle of the Atokan, begin their ranges in the middle Atokan in the Illinois basin. Triquitrites sculptilis appears in the Kilbourn Formation of Iowa and in the middle Atokan in the eastern part of the Forest City basin. The species appears in the Hernshaw coal (Kosanke, 1988) and Lower Chilton coal (Eble, 1994) of West Virginia and in the Big Mary coal bed in Tennessee, which correlate with the middle Atokan (Peppers, 1996). It appears in the upper Westphalian A (?) to upper Westphalian B (Paproth et al., 1983) in Europe. Spinosporites exiguus appears in the upper Atokan in Iowa (Ravn, 1986), and the upper part of the lower Atokan in Missouri and in the Windrock coal bed in Tennessee. Latosporites minutus also appears in the Windrock coal and in the middle of the upper Atokan in Missouri.

Triquitrites bransonii begins its range in the middle Atokan in Illinois (fig. 3). It appears in the Chilton " $A$ " coal bed in West Virginia (Kosanke, 1988), and in the upper Pioneer coal bed in Tennessee, which are middle Atokan in age. It occurs for the first time in Great Britain a little later, in middle Westphalian C. Microreticulatisporites sulcatus is a guide fossil for the middle Atokan and younger rocks in Illinois. It was recorded with reservation in the upper Atokan of Iowa (Ravn, 1986). It appears at about the middle of the Kanawha Formation in West Virginia (Eble, 1994). The Windrock coal, which is a little older than middle Atokan, is the oldest coal in Tennessee that contains M. sulcatus. Smith and Butterworth (1967) reported the first occurrence of the species in lower Westphalian C coals in Great Britain. Vestispora fenestrata appears in middle Atokan coals in Illinois and in the Kilbourn Formation in Iowa but does not appear until the middle of the upper half of the Atokan in the Missouri part of the Forest City basin (fig. 3).

It is first observed in the Hernshaw coal in West Virginia (Kosanke, 1988) and the upper Pioneer coal bed in Tennessee, both of which are slightly older than middle Atokan (Peppers, 1996). Vestispora fenestrata begins its range in lower Westphalian C coal beds in Europe (Clayton et al., 1977; Paproth et al., 1983).

Torispora securis, which begins its range in the middle Atokan in Illinois, is rare in the Forest City basin of Missouri as it was observed in only one coal. It does not occur until late Atokan in Iowa (Ravn, 1986) and equivalent coals in the Appalachian coal region (Eble and Gillespie, 1989; Kosanke, 1988; Peppers, 1996). The beginning of the range of Torispora is considered a good marker for the lower Westphalian C (Clayton et al., 1977; Paproth et al., 1983).

Ahrensisporites guerickei var. ornatus occurs for the last time in the shale of maceration 3295E in eastern Kansas. In the Illinois basin, it extends to the Mariah Hill Coal Member in the upper part of the Atokan. In Iowa, A. guerckei var. ornatus disappears between the middle and upper Atokan. It extends to 
the Pine Bald coal bed in Tennessee (Phillips and Peppers, 1984) and the Coalburg coal bed in West Virginia (Kosanke, 1988), both of which correlate with the upper Atokan. In Europe it extends to middle Westphalian C coals. Lophotriletes rarispinosus, which first appears in the middle Atokan in the Illinois basin, also occurs in maceration 3295E.

No coals or carbonaceous shales with spore assemblages occur between the shales of macerations 3295E and G, an interval of about $37 \mathrm{ft}$. Thus, no palynological data were obtained from the core between the middle and upper part of the Atokan.

The carbonaceous shale of maceration 3295G correlates with about the middle of the Radiizonates difformis (RD) Spore Assemblage Zone in the Illinois basin and is late Atokan in age. The shale marks the beginning of the stratigraphic range of Cyclogranisporites orbicularis and the only occurrence of Radiizonates rotatus and $R$. difformis. In Illinois the latter two species are found in only the Pope Creek and Tarter Coal Members. In Indiana they appear in the Upper Block and Lower Block Coal Members, which are equivalent to the Illinois coals, and the Mariah Hill Coal, which is slightly older than the Tarter Coal. In Iowa Radiizonates difformis appears in the upper Atokan Blackoak Coal, which is approximately correlative with a position between the Pope Creek and Rock Island (No. 1) Coals. No coal beds equivalent to the Tarter or Mariah Hill Coals have been identified in Iowa. The Radiizonates rotatus-R. difformis interval is thicker in the Appalachian region and contains more coals than in Illinois. The interval extends from the Winifrede to the Stockton coal beds in the Kanawha Formation in West Virginia (Eble, 1994), although Kosanke (1988) reported that the species appears slightly earlier, in the Chilton " $A$ " coal bed. It ranges from the Hazard No. 6 coal bed to Hazard No. 9 coal bed in eastern Kentucky and from the Coal Gap coal bed to an unnamed coal at the top of Cross Mountain in Tennessee (Peppers, 1996). All of these coals are equivalent in age to late Atokan.

Cyclogranisporites orbicularis first appears in the Mariah Hill Coal in the Illinois basin and the Blackoak Coal in Iowa, which are late Atokan in age. It began its stratigraphic range in the Peewee coal bed of Tennessee and in the Hazard No. 7 coal bed in eastern Kentucky, which are both late Atokan in age. Cyclogranisporites obliquus, which merges with some forms of C. orbicularis, appears in upper Westphalian C coals in Great Britain (Smith and Butterworth, 1967), but it has been reported in lower Westphalian C coals (Loboziak, 1971).

Dictyotriletes bireticulatus, Densosporites annulatus, Cristatisporites indignabundus, and Savitrisporites nux disappeared above the shale macerated as 3295G. The later two species disappeared above the Pope Creek Coal in Illinois and above the Blackoak Coal in Iowa. These two coals are late Atokan in age. Cristatisporites indignabundus disappears in the upper part of the unnamed upper Atokan succession in the Forest City basin (Peppers et al., 1993). It last occurs in the Coalburg coal in West Virginia, the Peewee coal in Tennessee, and the Hazard No. 7 coal and Princess No. 6 coal bed (Kosanke, 1973) in Kentucky, which are all late Atokan in age. Cristatisporites indignabundus extended to the end of Westphalian C in Europe (Loboziak, 1971; Coquel, 1976). Savitrisporites nux is so rare in the Forest City basin in Missouri that its range cannot be determined there. It disappears above the Princess No. 5 coal bed in northeastern Kentucky (Kosanke, 1973) and the Rock Springs coal bed in Tennessee. In Europe its range reaches almost to the top of Westphalian C.

Densosporites annulatus last occurs in the Tarter Coal in Illinois and in the Lower Block Coal in Indiana. It extends to the Blackoak Coal in Iowa and to almost the top of the Atokan in the Forest City basin in Missouri. It disappears above the Lower No. 5 Block coal bed (Kosanke, 1988) in the Pennsylvanian stratotype in West Virginia proposed by the U.S. Geological Survey (Englund et al., 1979). That coal correlates with the upper Atokan in the Illinois basin. Densosporites annulatus extends to the Hazard No. 9 coal in Kentucky and to an unnamed coal just above the Cold Gap coal in Tennessee. It ranges up to the top of Westphalian C in Europe (Loboziak, 1971; Coquel, 1976).

Dictyotriletes bireticulatus extends to the Rock Island (No. 1) coal in Illinois but extends slightly higher into an unnamed coal (formerly Indiana Coal II) directly above the Perth Limestone Member in Indiana (Peppers, 1996). It last occurs in the youngest unnamed Atokan coal in the eastern part of the Forest City basin and in the Blackoak coal in Iowa. Dictyotriletes bireticulatus disappears above the Upper No. 5 Block coal bed in West Virginia and the Hazard No. 8 coal bed in eastern Kentucky (Peppers, 1996). In Europe it extends into the basal part of Westphalian D. Savitrisporites concavus also occurs in maceration 3295G. It becomes extinct in the upper part of the Atokan in the Illinois basin and in the upper part of the Kilbourn Formation in Iowa.

The coal (macerations 3289 C-D) from 1,074.7 to $1,075.5 \mathrm{ft}$ (327-328 m) (table 2) correlates with the base of the Cadiospora magna-Mooreisporites inusitatus (MI) Spore Assemblage Zone in the Illinois basin (Peppers, 1984) and is early Desmoinesian in age (fig. 3). Vestispora clara, Triquitrites minutus, and Camptotriletes confertus appear for the first time in the coal and in the earliest Desmoinesian coal beds in the Illinois basin. Vestispora clara begins its range in the Blackoak Coal, which is the youngest Atokan coal in Iowa (Ravn, 1986). In northwestern Missouri, however, it begins in the youngest Desmoinesian coal (Peppers et al., 1993). This species has not been reported in Europe.

Triquitrites minutus appears in the Blackoak Coal but was not observed in the Forest City basin in Missouri. The species was reported by Kosanke (1988) in the Upper No. 5 Block coal (early Desmoinesian) in West Virginia, but it is rare in the Applachian region. Camptotriletes confertus was observed only in macerations $3289 \mathrm{C}$ and D, and in Iowa it appears only in the Blackoak Coal. It has not been reported in the Forest City basin or Appalachian coal region.

Endosporites zonalis last occurs in macerations 3289 C and D. It ranges up to the Hermon Coal Member at the base of the Desmoinesian in Illinois but was not observed in the Desmoinesian in the eastern part of the Forest City basin. The species extends up to the Laddsville Coal Member in Iowa, which is slightly younger than the Hermon Coal. In the U.S Geological Survey proposed Pennsylvanian stratotype, E. zonalis disappears above the Little No. 5 Block coal bed, which is late Atokan in age. It extends into the lower Westphalian D in Great Britain (Smith and Butterworth, 1967). A few specimens of Laevigatosporites cf. vulgaris, a thickened form of L. vulgaris, were observed in maceration 3289D. In the Illinois basin it occurs in the Lewisport coal bed near the base of the Desmoinesian. 
No major changes in spore assemblages occur between the coal of macerations 3289C-D at the base of the Desmoinesian and the coal of macerations 3289E-F, which is the Riverton coal bed.

\section{Relative Abundance of Spore Taxa in Coal and Carbonaceous Shale}

The relative abundance of spore taxa can be useful in a general way in characterizing and correlating coal beds (figs. 3 and 4). Lycospora pellucida dominates the spore assemblages in the two oldest coal beds and oldest carbonaceous shale in the Kansas Geological Survey Edmonds 1A core. Lycospora granulata, Densosporites annulatus, and other lycopod spores make up most of the remainder of the assemblages in the three samples. In the Illinois basin $D$. annulatus is most abundant in the Reynoldsburg Coal Bed at the base of the Tradewater Formation (top of the Morrowan) and several overlying lower Atokan coal beds. Ravn (1986) noted that in Iowa the species tends to be most abundant in the lower Atokan Kilbourn Formation.

Maceration 3295B (fig. 4) of the shale band is dominated by Densosporites sphaerotriangularis at $45 \%$, but Lycospora pellucida at $17 \%$ is still the dominant species of Lycospora. In maceration 3295C Lycospora granulata at 32\% becomes the most abundant species, and Densosporites sphaerotriangularis at $18.5 \%$ is second in abundance. Although L. granulata is still the most abundant species in macerations 3295D and E, Lycospora micropapillata becomes a significant component at 16.5 and $18.5 \%$, respectively. Lycospora granulata remains as the most abundant species in the youngest carbonaceous shale (macerations 3295G) and in the remainder of the core samples. Florinites, large species of Laevigatosporites, and fern spores including Punctatosporites minutus and Laevigatosporites globosus become important constituents in the floras for the first time. Lycospora granulata becomes even more abundant in the upper two coals reaching a maximum of 52.5\% in the upper half of the coal (maceration 3289F) at the base of the Desmoinesian. Fern spores Punctatisporites minutus, Punctatosporites minutus, Latosporites minutus, Torispora securis, Triquitrites spp., and Granulatisporites spp. also became more abundant in the upper shale (maceration 3295G) and coals.

The pattern of change in dominance of three species of Lycospora in the Middle Pennsylvanian is apparently concurrent over a large area of North America (Peppers, 1979; Phillips et al., 1985; Peppers, 1996). Lycospora pellucida is dominant in Lower and lower Middle Pennsylvanian coals, up to a little below the middle of the Atokan in the Illinois and Forest City basins (Peppers et al., 1993) and in the lower part of the Middle Pennsylvanian (middle Westphalian B) in the Appalachian region. Lycospora granulata become the most abundant species of Lycospora for a brief time. This was followed by a short interval in which L. micropapillata was abundant or dominant. This marked increase in abundance of $L$. micropapillata also occurs in western Missouri (Peppers et al., 1993), Illinois, Kentucky, and Tennessee (Peppers, 1979), and West Virginia (Kosanke, 1988) just before the middle of the Atokan. The interval between the shales of maceration 3295B and 3295C probably represents a longer time than indicated by the thickness of the interval because in most regions several coal beds are dominated by $L$. granulata before L. micropapillata becomes abundant. Lycospora micropapillata declined in abundance in the middle Atokan. Lycospora granulata then became dominant again and remained so until the end of the Desmoinesian (fig. 4) at which time Lycospora essentially disappeared in North America.

A key element in spore distribution and its use in correlation is the rise of ferns, especially tree ferns. Laevigatosporites globosus and Punctatosporites minutus began to be an important part of coal swamp floras a little after the middle of the Atokan in the Illinois basin as represented by the shale of maceration 3295G in Kansas. The epibole of the two species as indicated in fig. 3 occurred somewhere between that shale and the shale of maceration 3295E because there is a relatively large interval between the two shale beds. The base of the epibole of Torispora, another tree fern spore, is at the Tarter Coal in the upper Atokan (upper Westphalian C) in Illinois and in the coal of maceration 3295G in Kansas. Punctatisporites minutus reaches epibole proportions near the end of the Atokan.

\section{Floral Composition of Coal Swamps and Clastic Mires}

As in the Illinois basin and Appalachian coal region, lycopod trees including Lepidophloios, Lepidodendron, and Paralycopodites dominated the early Atokan (Westphalian B) coal swamps and clastic wetlands. Small lycopods represented by Densosporites were very abundant in some of the mires. Tree lycopods continued to dominate in the Upper Atokan (Westphalian C) and lower Desmoinesian (Westphalian D), and smaller lycopods were rare. Tree ferns represented by Punctatisporites minutus, Punctatosporites minutus, Latosporites minutus, Laevigatosporites globosus, Torispora securis, and other minor species were not abundant until the upper Atokan. Filicalean ferns were somewhat more common in the lower Atokan than the tree ferns, but like the tree ferns they increased in abundance in the upper Atokan. Large species of Laevigatosporites, including L. vulgaris and L. desmoinesensis, produced by sphenopsids increased in abundance in the upper Atokan. Sphenopsids that produced Calamospora remained at about the same abundance throughout the Atokan and lower Desmoinesian. Florinites, the major cordaites spore, also did not undergo major changes in abundance. The abundance of seed ferns is not shown because the very large seed fern pollen Monoletes, borne by Medulosa, is not part of the small-spore population.

\section{Coal Samples from Cores Drilled in Cherokee County, Kansas}

Three additional coal samples from three closely spaced cores drilled by Gulf Oil Corporation (Pittsburg \& Midway PM1, PM-7, and PM-12) in Cherokee County, southeastern Kansas, were macerated and studied (fig. 1, table 1). Desorptions of the three Gulf-P\&M cores are graphically presented in Appendix A, which is an open-file report by Harris, 1984.

Maceration 3286 is of a coal between 389.9 and $390.5 \mathrm{ft}$ (118.8-119 m), $6.4 \mathrm{ft}$ (1.9 m) below the Riverton coal and 17 $\mathrm{ft}(5 \mathrm{~m}$ ) above the base of the Pennsylvanian in the Pittsburg \& Midway PM-1 core. The coal is early Desmoinesian (early Westphalian D) in age and is approximately equivalent to the 


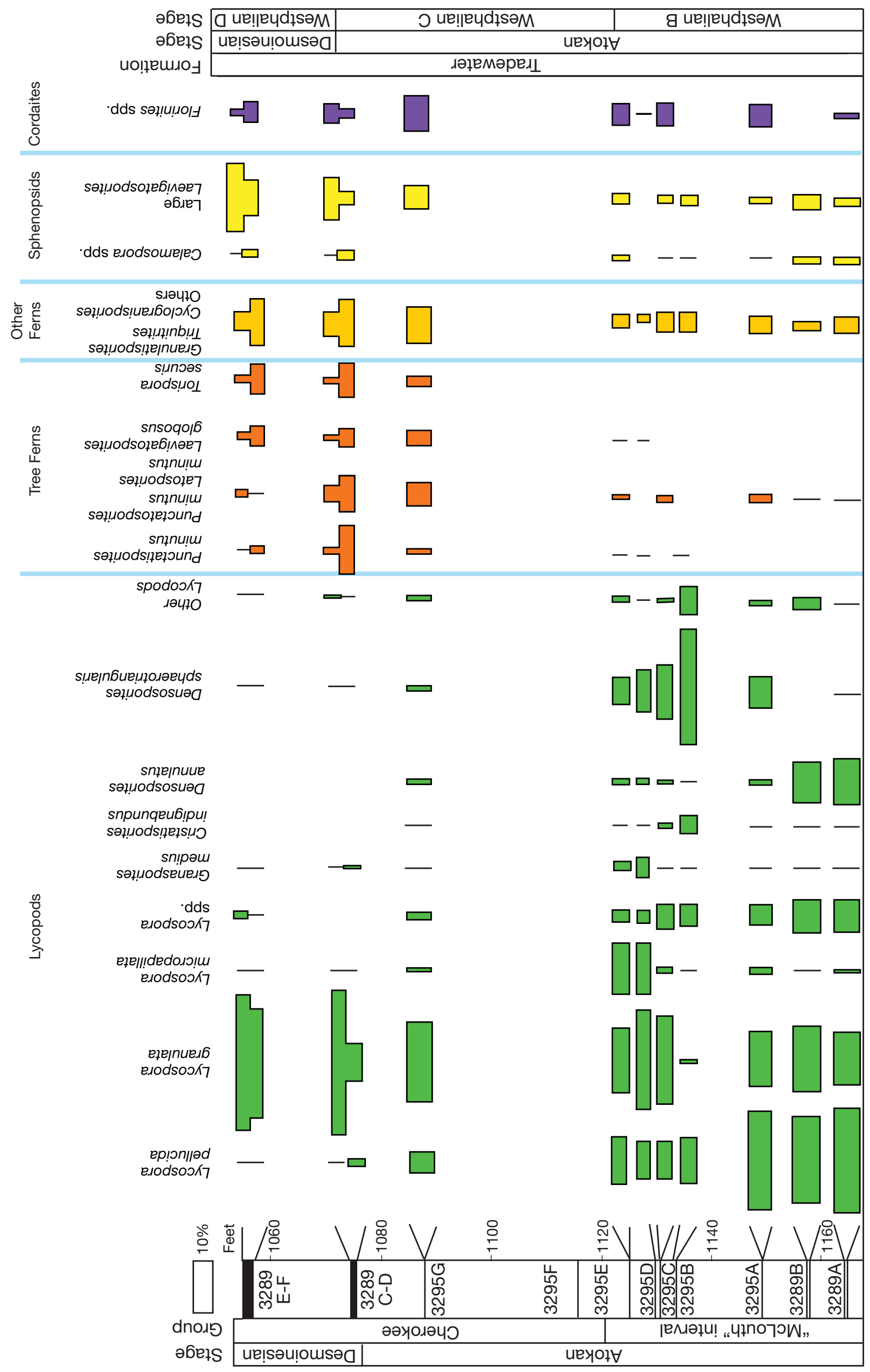


Lewisport coal in the Illinois basin. It contains Thymospora pseudothiessenii (fig. 5 and table 3), which begins its range at the base of the Desmoinesian in the Illinois basin. The species appears in the Upper No. 5 Block coal bed in the lower part of the Charleston Sandstone in West Virginia (Kosanke, 1988). In Europe T. pseudothiessenii is an index fossil for the base of Westphalian D. Anapiculatisporites grundensis, which also occurs in maceration 3286, first appears in the Lewisport coal in the Illinois basin. The relatively large percentage of Torispora,

Punctatosporites minutus, and Triquitrites sculptilis indicates that the coal is near the Atokan-Desmoinesian boundary. Maceration 3286 lacks the Atokan taxa Dictyotriletes bireticulatus, Radiizonates difformis, $R$. rotatus, Savitrisporites nux, and Cristatisporites indignabundus.

Lycopods, ferns, cordaites, and sphenopid spores are well represented in maceration 3286 (fig. 5). Lycospora granulata at $15.5 \%$ is the most abundant species. Fern spores present include Laevigatosporites globosus (6.5\%), Punctatosporites minutus (5.5\%), Torispora securis (5\%), Cyclogranisporites orbicularis (5\%), and Punctatisporites minutus (5\%). The cordaitean Florinites mediapudens accounts for $10 \%$ of the spore assemblage, and the sphenopsid spores Laevigatosporites desmoinesensis and $L$. ovalis are at $11 \%$ each.

Maceration 3287 is a coal between 449.6 and $450.0 \mathrm{ft}$ (137$137.2 \mathrm{~m}$ ) in Pittsburg and Midway PM-7 core. It is just above the top of the Mississippian limestone and is $27.2 \mathrm{ft}(8.3 \mathrm{~m})$ below the Riverton coal. The coal is late Atokan in age. Maceration 3287 contains Densosporites annulatus (fig. 4), which extends up to the Tarter Coal in Illinois, and Vestispora fenestrata, Microreticulatisporites sulcatus, Torispora securis, and Triquitrites sculptilis, which first appear at about middle Atokan. Therefore, the coal is no older than the shale band macerated as 3295E in the Edmonds No. 1A core. Laevigatosporites

\section{Summary and Conclusions}

Palynology of coal beds and carbonaceous shale bands from cores in Leavenworth and Cherokee counties, Kansas, has led to a correlation of Atokan and lower Desmoinesian strata between eastern Kansas and the Illinois basin. Correlations are also made between eastern Kansas, the Forest City basin in northwestern Missouri, Iowa, the Appalachian coal region, and western Europe. The spore assemblage zonation of the Illinois basin is extended to eastern Kansas.

The oldest Pennsylvanian coal in the Kansas Geological Survey Edmonds No. 1A core in Leavenworth County, Kansas, is approximately equivalent to the Bell coal in the Illinois basin and is early Atokan in age (early Westphalian B). It correlates with the lower part of the Middle Pennsylvanian (U.S. Geological Survey usage). It is correlated with the lower part of the Microreticulatisporites nobilis-Endosporites globiformis (NG) Spore Assemblage Zone of the Illinois basin. This is based on the large abundance of Densosporites annulatus and the presence of Vestispora pseudoreticulata, Punctatosporites minutus, Waltzispora prisca, and Sinuspores sinuatus. The latter two species disappear above this coal. The oldest shale band (maceration 3295A), which is only about $15 \mathrm{ft}$ above the oldest coal, is in the middle of NG Spore Assemblage Zone and is a little older than middle Atokan (late Westphalian B). Cyclogranisporites aureus and Pilosisporites aculeolatus begin their stratigraphic ranges in the shale. The shale band correlates globosus and Latosporites minutus are also present, but their low abundance indicates that the coal is about the same age as the shale macerated as 3295E. The coal lacks Radiizonates difformis and $R$. rotatus; therefore, the coal is older than the Mariah Hill Coal of Indiana.

Lycospora pellucida and L. granulata at $27.5 \%$ each are equally represented. Lycospora micropapillata and Endosporites globiformis each make up $6.5 \%$ of the assemblage. These percentages also indicate that the coal is about middle Atokan in age because L. pellucida is replaced by L. granulata as the dominant species of Lycospora during middle Atokan, and L. micropapillata is unusually abundant slightly later. The low abundance of Punctatosporites minutus (6.5\%), Punctatisporites minutus (1.5\%), Latosporites minutus (1.5\%), and Triquitrites (4\%) indicate that ferns were not very abundant. Laevigatosporites desmoinesensis (5.5\%) and L. ovalis (5\%) represented sphenopsid plants. The cordaites pollen Florinites accounts for only $2 \%$ of the assemblage.

Maceration 3288 is of a coal between 435.7 and $437.3 \mathrm{ft}$ (132.8-133 m) in the Pittsburg and Midway PM-12 core. The coal directly overlies Mississippian limestone and is $25.5 \mathrm{ft}$ (7.8 $\mathrm{m})$ below the Riverton coal. The spore assemblage is rather poorly preserved; therefore, relative abundance of spore taxa were not determined. The coal contains Lophotriletes gibbosus, which extends to the Rock Island (No. 1) Coal in Illinois, but into the Desmoinesian in Iowa (Ravn, 1986). Triquitrites minutus (fig. 4), which first appears in the Rock Island Coal in Illinois and the Blackoak Coal in Iowa, was also observed in maceration 3288. Torispora and Triquitrites sculptilis are more abundant than in maceration 3287, which is older than the coal of 3288. The coal of maceration 3288 is close to the Atokan-Desmoinesian boundary.

with the Kilbourn Formation in Iowa and the middle of the Kanawha Formation in West Virginia.

Several important palynologic events occurred during deposition of four shale bands (macerations 3295B-E) within an interval of $8 \mathrm{ft}(2.4 \mathrm{~m})$. The lower three bands are placed in the upper part of the NG Spore Assemblage Zone. The upper shale band (maceration 3295E) is in the lower part of the Torispora securis-Vestispora fenestrata (SF) Spore Assemblage Zone. The shale bands are middle Atokan in age and are present at the Westphalian B-C transition. They are correlated with an interval just below the Smith Coal in the Illinois basin because of appearance of a large number of species: Punctatisporites minutus, Verrucosisporites sifati, Endosporites plicatus, Laevigatosporites globosus, Triquitrites sculptilis, T. bransonii, Vestispora fenestrata, Torispora securis, Spinosporites exiguus, Latosporites minutus, and Microreticulatisporites sulcatus.

The youngest shale band (maceration 3295G) is in the Radiizonates difformis (RD) Spore Assemblage Zone, which is late Atokan (late Westphalian C) in age. The shale is approximately equivalent to the Tarter Coal in Illinois. The shale is characterized by the presence of Radiizonates difformis and Cyclogranisporites orbicularis and the last appearance of Cristatisporites indignabundus, Densosporites annulatus, and Savitrisporites пux. 


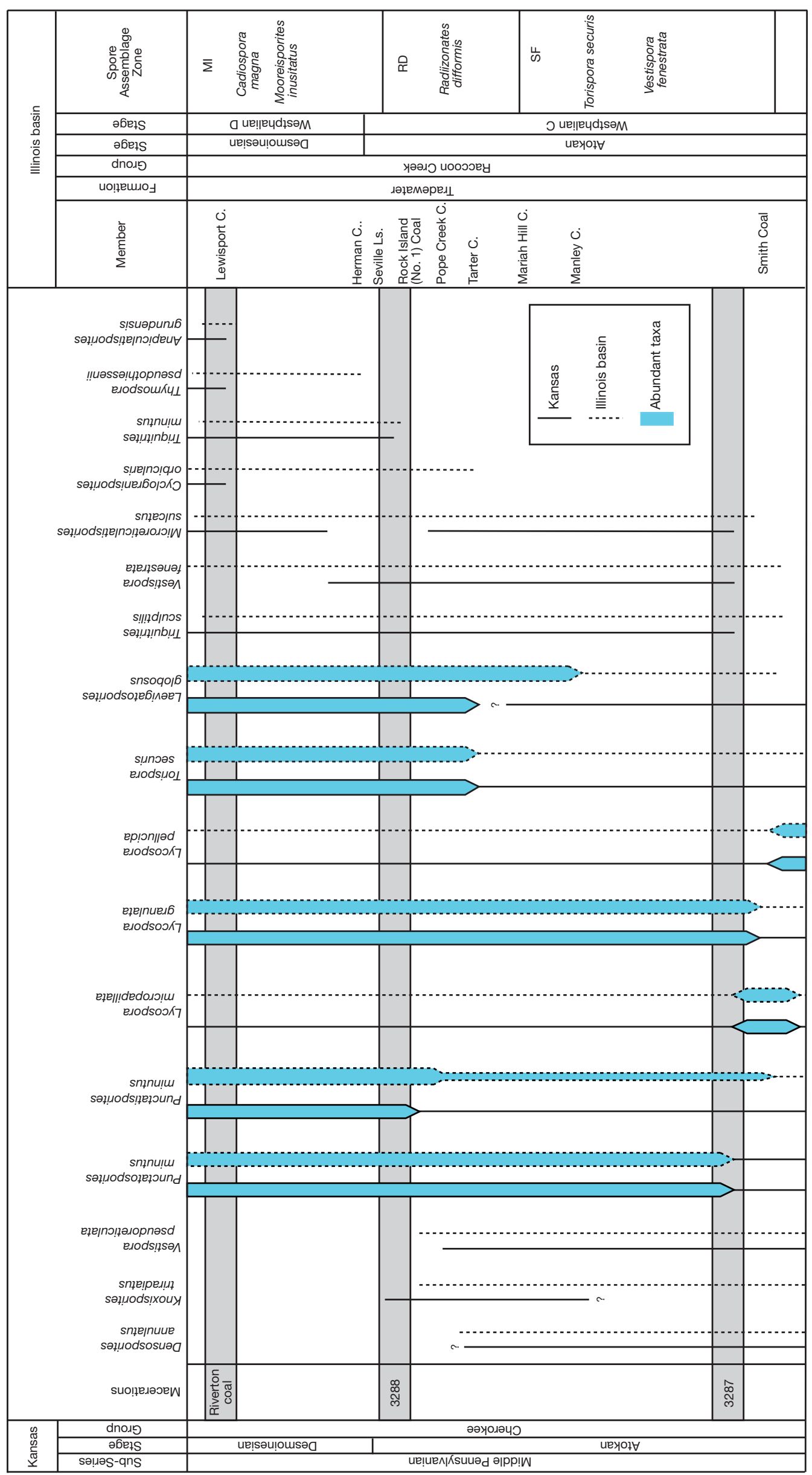


TABLE 3-Palynology of oldest Pennsylvanian coal beds in three cores from Cherokee County, Kansas. Numbers are percent of taxon in the spore assemblage, and " $\mathrm{X}$ ” indicates taxon present but not observed in spore count.

\begin{tabular}{|c|c|c|c|c|c|c|c|}
\hline & 3286 & 3287 & 3288 & & 3286 & 3287 & 3288 \\
\hline Deltoidospora pseudolevis & & $\mathrm{X}$ & $\mathrm{X}$ & Reticulatisporites falsus & & & $\mathrm{X}$ \\
\hline D. subadnatoides & 0.5 & & & R. reticulatus & $\mathrm{X}$ & & \\
\hline Punctatisporites flavus & $\mathrm{X}$ & & & Crassispora kosankei & $\mathrm{X}$ & $\mathrm{X}$ & $\mathrm{X}$ \\
\hline P. glaber & 1.0 & & & & & & \\
\hline P. minutus & 4.0 & 1.5 & & Granasporites medius & 3.5 & 2.5 & \\
\hline \multirow[t]{2}{*}{$P$ sp. } & $\mathrm{X}$ & 0.5 & & & & & \\
\hline & & & & Densosporites annulatus & & $\mathrm{X}$ & $\mathrm{X}$ \\
\hline Calamospora breviradiata & 0.5 & 0.5 & & D. sphaerotriangularis & & 0.5 & \\
\hline C. hartungiana & $\mathrm{X}$ & & & & & & \\
\hline \multirow[t]{2}{*}{ C. mutabilis } & $\mathrm{X}$ & $\mathrm{X}$ & & Lycospora brevijuga & & 0.5 & \\
\hline & & & & L. granulata & 15.5 & 27.5 & $\mathrm{X}$ \\
\hline Granulatisporites granularis & 0.5 & & & L. micropapillata & 2.0 & 6.5 & \\
\hline \multirow[t]{2}{*}{ G. minutus } & 1.5 & & & L. pellucida & & 27.5 & $\mathrm{X}$ \\
\hline & & & & L. pusilla & 1.0 & 0.5 & \\
\hline Cyclogranisporites aureus & & $\mathrm{X}$ & $\mathrm{X}$ & & & & \\
\hline C. minutus & 1.0 & & & Cirratriradites annulatus & $\mathrm{X}$ & & \\
\hline C. orbicularis & 5.0 & & & C. saturnii & & & $\mathrm{X}$ \\
\hline \multirow[t]{2}{*}{ C. sp. } & 1.0 & & & & & & \\
\hline & & & & Endosporites globiformis & 1.0 & 6.5 & $\mathrm{X}$ \\
\hline Verucosisporites microtuberosus & & & $\mathrm{X}$ & E. plicatus & $\mathrm{X}$ & & $\mathrm{X}$ \\
\hline$V$. sifati & $\mathrm{X}$ & & & & & & \\
\hline$V$. sp. & & $\mathrm{X}$ & & Alatisporites pustulatus & $\mathrm{X}$ & & \\
\hline Lophotriletes commissuralis & & & $\mathrm{X}$ & Laevigatosporites desmoinesensis & 11.0 & 5.5 & $\mathrm{X}$ \\
\hline L. gibbosus & & & $\mathrm{X}$ & L. globosus & 6.5 & $\mathrm{X}$ & $\mathrm{X}$ \\
\hline L. pseudaculeatus & & $\mathrm{X}$ & & L. medius & 1.5 & & $\mathrm{X}$ \\
\hline \multirow[t]{2}{*}{ L. rarispinosus } & $\mathrm{X}$ & & & L. ovalis & 11.0 & 5.0 & $\mathrm{X}$ \\
\hline & & & & L. striatus & $\mathrm{X}$ & & \\
\hline Anapiculatisporites grundensis & 0.5 & & & L. vulgaris & 0.5 & & \\
\hline Apiculatasporites setulosus & & $\mathrm{X}$ & & Latosporites minutus & 2.5 & 1.5 & \\
\hline Pilosisporites aculeolatus & $\mathrm{X}$ & & & Punctatosporites minutus & 5.5 & 6.5 & $\mathrm{X}$ \\
\hline Raistrickia abdita & & $\mathrm{X}$ & $\mathrm{X}$ & Spinosporites exiguus & & 0.5 & \\
\hline R. breveminens & 1.0 & 0.5 & $\mathrm{X}$ & & & & \\
\hline R. crocea & 0.5 & $\mathrm{X}$ & & Thymospora pseudothiessenii & 0.5 & & \\
\hline R. irregularis & & $\mathrm{X}$ & $\mathrm{X}$ & & & & \\
\hline R. pilosa & $\mathrm{X}$ & & & Torispora securis & 5.0 & $\mathrm{X}$ & $\mathrm{X}$ \\
\hline Convolutispora florida & $\mathrm{X}$ & $\mathrm{X}$ & & Vestispora fenestrata & & $\mathrm{X}$ & $\mathrm{X}$ \\
\hline \multirow[t]{2}{*}{ C. sp. } & & $\mathrm{X}$ & & V. laevigata & 0.5 & & \\
\hline & & & & V. pseudoreticulata & & $\mathrm{X}$ & \\
\hline Microreticulatisporites nobilis & $\mathrm{X}$ & & $\mathrm{X}$ & & & & \\
\hline \multirow[t]{2}{*}{ M. sulcatus } & $\mathrm{X}$ & $\mathrm{X}$ & & Florinites mediapudens & 10.0 & 1.5 & $\mathrm{X}$ \\
\hline & & & & F. millottii & & 0.5 & \\
\hline Triquitrites additus & & & $\mathrm{X}$ & F. similis & $\mathrm{X}$ & $\mathrm{X}$ & \\
\hline T. bransonii & 1.0 & 1.5 & & F. visendus & & $\mathrm{X}$ & $\mathrm{X}$ \\
\hline T. exiguus & 2.5 & 0.5 & & & & & \\
\hline T. minutus & & & $\mathrm{X}$ & Wilsonites delicatus & & $\mathrm{X}$ & \\
\hline T. sculptilis & 2.0 & 0.5 & $\mathrm{X}$ & W. vesicatus & $\mathrm{X}$ & & $\mathrm{X}$ \\
\hline T. tribullatus & $\mathrm{X}$ & 0.5 & & Quasillinites diversiformis & & & $\mathrm{X}$ \\
\hline \multirow[t]{2}{*}{ T. sp. } & & 1.0 & & & & & \\
\hline & & & & Centonites symmetricus & & & $\mathrm{X}$ \\
\hline Knoxisporites stephanephorus & & $\mathrm{X}$ & & & & & \\
\hline
\end{tabular}


The coal macerated as 3289C and D is at the base of the Desmoinesian (base of Westphalian D) and is correlated with the base of the Cadiospora magna-Mooreisporites inusitatus (MI) Spore Assemblage Zone. It is a little younger than the Seville Limestone in Illinois. The coal marks the appearance of Triquitrites minutus, Camptotriletes confertus, and Vestispora clara and the last appearance of Endosporites zonalis. The youngest coal sampled, which is the Riverton coal, in the KGS Edmonds No. 1A core is early Desmoinesian (early Westphalian D) in age. It is approximately equivalent to the Lewisport coal in the Illinois basin. This confirms the conclusions of Morgan (1955), Wilson (1970), and Rosowitz (1982) that the Riverton coal is early Desmoinesian in age.

Three coal beds that are present just above the base of the Pennsylvanian in three cores drilled in Cherokee County, southeastern Kansas, range in age from middle Atokan to early Desmoinesian.

Several aspects of changing palynological assemblages during middle Atokan suggest the initiation of a time in which less moisture was available, at least seasonally. These changing patterns have been found elsewhere in the Illinois basin (Peppers, 1979, 1996), the Forest City basin in western Missouri (Peppers et al., 1993), and Appalachian coal region (Phillips and Peppers, 1984: Phillips et al., 1985). Lycospora pellucida was the dominant spore species until the middle Atokan at which time Lycospora granulata became dominant. Soon afterward, Lycospora micropapillata, produced by Paralycopodites, briefly increased in abundance. This interval correlates with the "dried interval” of Paralycopodites-dominated coal swamps discussed by Peppers (1979). Felix (1954) also described specimens of what would be classified as L. micropapillata from the tips of Lepidostrobus cones. He considered these small forms of Lycospora as abortive spores and thought that the lycopods may have been growing under stress due to reduced available moisture.

Lycospora granulata again became the dominate species of Lycospora until the genus disappeared at the end of the Desmoinesian. Spores produced by ferns, which generally occupied drier habitats than those of lycopods, began to increase in abundance during this same time. Finally, the middle Atokan was also characterized by the introduction of a number of species of spores, most of which belonged to the ferns.

\section{ACKNOWLEDGMENTS-Careful review of the} manuscript was provided by Brian J. Cardott of the Oklahoma Geological Survey and Cortland F. Eble of the Kentucky Geological Survey. Their suggestions on the stratigraphy and palynology were important to development of the final paper. At the Kansas Geological Survey, Marla Adkins-Heljeson provided editorial review of the manuscript, and Jennifer Sims provided the graphic work for the figures. Several of the figures were based on earlier graphic work by the Illinois Geological Survey for the poster paper where parts of this work were originally presented.

\section{References}

Abernathy, G. E., 1937, The Cherokee Group of southeastern Kansas: Kansas Geological Society, Guidebook, $11^{\text {th }}$ Annual Field Conference, Southeastern Kansas, Northeastern Oklahoma, Sept. 3-6, 1937, p. 18-23.
Bond, T. A., 1963, Palynology of the Weir-Pittsburg coal (Pennsylvanian) of Oklahoma and Kansas: M.S. thesis, University of Oklahoma, Norman, 103 p.

Bordeau, K. V., 1964, Palynology of the Drywood coal (Pennsylvania) of Oklahoma: M.S. thesis, University of Oklahoma, Norman, 207 p.

Brady, L. L., Nuelle, L. M., Haug, D. B., Smith, D. C., Bostic, J. L., and Jaquess, J. C., 1994, Coal resources of the Joplin $1^{\circ} \times 2^{\circ}$ quadrangle, Kansas and Missouri: U.S. Geological Survey, Miscellaneous Investigations Series, Map I-2426-A, 2 sheets.

Branson, C. C., 1962, Pennsylvanian System of the midcontinent; in, Pennsylvanian System in the United States-A Symposium, C. C. Branson, ed.: American Association of Petroleum Geologists, Tulsa, Oklahoma, p. 431-460.

Clarke, R. T., 1961, Palynology of the Secor coal (Pennsylvanian) of Oklahoma: M.S. thesis, University of Oklahoma, Norman, 131 p.

Clayton, G., Coquel, R., Doubinger, J., Gueinn, K. J., Loboziak, S., Owens, B., and Streel, M., 1977, Carboniferous miospores of western Europe-Report of Commission Internationale de Microflore du Paléozoic Working Group on Carboniferous Stratigraphic Palynology: Mededelingen Rijks Geologische Dienst, v. 29, $71 \mathrm{p}$.

Clopine, W. W., 1991, Lithostratigraphic and biostratigraphic analysis of the Atokan Series (Middle Pennsylvanian) in the Ardmore basin, Oklahoma: Compass, v. 68, p. 221-232.

Coquel, R., 1976, Étude palynologique de la Série houillère dans l'unité de production de Valenciennes du Basin le houillère du Nord de la France: Palaeontographica, v. 156B, p. 12-64.

Davis, P. N., 1961, Palynology of the Rowe coal (Pennsylvanian) of Oklahoma: M.S. thesis, University of Oklahoma, Norman, 153 p.

Dempsey, J. E., 1964, A palynological investigation of the lower and upper McAlester coals (Pennsylvanian) of Oklahoma: Ph.D. dissertation, University of Oklahoma, Norman, 124 p.

Dolly, E. D., 1965, Palynology of the Bevier coal (Pennsylvanian) of Oklahoma: M.S. thesis, University of Oklahoma, Norman, 114 p.

Eble, C. F., 1994, Palynostratigraphy of selected Middle Pennsylvanian coal beds in the Appalachian basin; in, Elements of Pennsylvanian Stratigraphy, Central Appalachian Basin, C. L. Rice, ed.: Geological Society of America, Special Paper 294, p. 55-68.

Eble, C. F., 1996, Lower and Middle Pennsylvanian coal palynofloras, southwestern Virginia: International Journal Coal Geology, v. 31, p. 67-113.

Eble, C. F., and Gillespie, W. H., 1989, Palynology of selected Pennsylvanian coal beds from the central and southern Appalachian basin-Correlation and stratigraphic implications; in, Coal and Hydrocarbon Resources of North America; Volume 2, Characteristics of the Mid-Carboniferous Boundary and Associated Coal-bearing Rocks in the Appalachian Basin (28 ${ }^{\text {th }}$ International Geological Congress, Field Trip Guidebook T352), K. J. Englund, ed.: Washington, D.C., American Geophysical Union, p. 61-66.

Englund, K. J., Arndt, H. H., and Henry, T. W., eds., 1979, Proposed Pennsylvanian System stratotype, Virginia and West Virginia: Ninth International Congress of Carboniferous Stratigraphy and Geology, American Geological Institute, Guidebook Series 1, 138 p.

Fay, R. O., Friedman, S. A., Johnson, K. S., Roberts, J. F., Rose, W. D., and Sutherland, P. K., 1979, The Mississippian and Pennsylvanian (Carboniferous) Systems in the United States-Oklahoma: U. S. Geological Survey, Professional Paper 1110-R, 35 p.

Felix, C. J., 1954, Some American arborescent lycopod fructifications: American Monthly Botanical Garden, v. 41, p. 351-394.

Felix, C. J., and Burbridge, P. P., 1967, Palynology of the Springer Formation of southern Oklahoma, USA: Palaeontology, v. 10, p. 349-425.

Gibson, L. B., 1961, Palynology and paleoecology of the Iron Post coal (Pennsylvanian) of Oklahoma: Ph.D. dissertation, University of Oklahoma, 239 p.

Harris, J. W., 1984, Stratigraphy and depositional environments of the Krebs Formation-lower Cherokee Group (Middle Pennsylvanian) 
in southeastern Kansas: Kansas Geological Survey, Open-file Report 84-9, 139 p.

Haworth, E., and Kirk, M. Z., 1894, A geologic section along the Neosho River from the Mississippian formation of the Indian Territory to White City, Kansas, and along the Cottonwood River from Wyckoff to Peabody: Kansas University Quarterly, v. 2, p. 104-115.

Higgins, M. J., 1961, Stratigraphic position of the coal seam near Potter, Wagoner County, Oklahoma: M.S. thesis, University of Oklahoma, Norman, 83 p.

Hopkins, M. E., and Simon, J. A., 1975, Pennsylvanian System; in, Handbook of Illinois Stratigraphy, H. B. Willman, E. Atherton, T. C. Buschback, C. Collinson, M. E. Hopkins, J. A. Lineback, and J. S. Simon, eds.: Illinois State Geological Survey, Bulletin 95, p. 163-201.

Howe, W. B., 1956, Stratigraphy of pre-Marmaton Desmoinesian (Cherokee) rocks in southeastern Kansas: Kansas Geological Survey, Bulletin 123, 132 p.

Huffman, D. P., 1991, Stratigraphy and depositional environments of the Cherokee Group (Middle Pennsylvanian) Bourbon Arch region, east-central Kansas: Kansas Geological Survey, Open-file Report 91-65, 144 p.

Jewett, J. M., O’Connor, H. G., and Zeller, D. E., 1968, Pennsylvanian System; in, The Stratigraphic Succession in Kansas, D. E. Zeller, ed.: Kansas Geological Survey, Bulletin 189, p. 21-43.

Jones, D. H., 1957, Palynology of the Bevier coal of Missouri: M.S. thesis, University of Missouri, Columbia, $147 \mathrm{p}$.

Keyes, C. R., 1896, Serial nomenclature of the Carboniferous: American Geologist, v. 18, p. 22-28.

Kosanke, R. M., 1950, Pennsylvanian spores of Illinois and their use in correlation: Illinois State Geological Survey, Bulletin 74, 128 p.

Kosanke, R. M., 1973, Palynological studies of the coals of the Princess Reserve District in northeastern Kentucky: U.S. Geological Survey, Professional Paper 839, 22 p.

Kosanke, R. M., 1984, Palynology of selected coal beds in the proposed Pennsylvanian System stratotype in West Virginia: U.S. Geological Survey, Professional Paper 1318, 44 p.

Kosanke, R. M., 1988, Palynological studies of Middle Pennsylvanian coal beds of the proposed Pennsylvanian System stratotype in West Virginia: U.S. Geological Survey, Professional Paper 1455, 73 p.

Kosanke, R. M., Simon, J. A., Wanless, H. R., and Willman, H. B., 1960, Classification of the Pennsylvanian strata of Illinois: Illinois State Geological Survey, Report of Investigations 124, 84 p.

Lambert, L. L., and Thompson, T. L., 1990, Age and significance of the “Ladden Branch” Limestone (Riverton Formation; Pennslvanian), west-central Missouri: Geological Society of America, Southcentral Section, Stillwater, Oklahoma, Abstracts with Program, v. 22, p. 13.

Lee, W., 1941, Preliminary report on the McLouth gas and oil field, Jefferson and Leavenworth counties, Kansas: Kansas Geological Survey, Bulletin 38, part 10, p. 261-284.

Loboziak, S., 1971, Les micro-et mégaspores de la partie occidentale du bassin houiller du Nord de la France: Palaeontographica, B 132, p. $1-127$.

Loboziak, S., Coquel, R., and Owens, B., 1984, Les microspores des Formations Hale and Bloyd du Nord de l' Arkansas; in, Biostratigraphy, P. K. Sutherland and W. M. Manger, eds.:Compte Rendu, Neuvième Congrès. International de Stratigraphie et de Géologie du Carbonifère, Washington and Champaign-Urbana, 1979, v. 2, p. 385-390.

Moore, R. C., 1936, Stratigraphic classification of the Pennsylvanian rocks of Kansas: Kansas Geological Survey, Bulletin 22, 256 p.

Moore, R. C., 1948, Classification of Pennsylvanian rocks in Iowa, Kansas, Missouri, Nebraska, and northern Oklahoma: American Association of Petroleum Geologists, Bulletin, v. 32, p. 2,0112,040 .

Moore, R. C., 1949, Divisions of the Pennsylvanian System in Kansas: Kansas Geological Survey, Bulletin 83, 203 p.
Moore, R. C., Frye, J. C., and Jewett, J. M., 1944, Tabular description of outcropping rocks in Kansas: Kansas Geological Survey, Bulletin 52, part 4, p. 137-212.

Moore, R. C., Wanless, H. R., Weller, J. M., Williams, J. S., Read, C. B., Bell, W. A., Ashley, G. H., Cheney, M. G., Cline, L. M., Condra, G. E., Dott, R. H., Dunbar, C. O., Elias, M. K., Glenn, L. C., Greene, F. C., Hendricks, T. A., Jewett, J. M., Johnson, J. H., King, P. B., Knight, J. B., Levorsen, A. I., Miser, H. D., Newell, N. D., Plummer, F. B., Thompson, M. L., Tomlinson, C. W., and Westheimer, J., 1944, Correlation of Pennsylvanian formations of North America: Geological Society of America, Bulletin, v. 55, p. 657-706.

Morgan, J. L., 1955, Spores of McAlester coal: Oklahoma Geological Survey, Circular 36, 52 p.

Nodine-Zeller, D. E., and Thompson, T. L., 1977, Age and structure of subsurface beds in Cherokee County, Kansas-Implications from endothyrid Formanifera and conodonts: Kansas Geological Survey, Bulletin 211, part 3, 11 p.

Owens, B., Loboziak, S., and Coquel, R., 1984, Late MississippianEarly Pennsylvanian miospore assemblages from northern Arkansas; in, Biostratigraphy, P. K. Sutherland and W. L. Manger, eds.: Compte Rendu, Neuvième Congrès. International de Stratigraphie et de Géologie du Carbonifère, Washington and Champaign-Urbana, 1979, v. 2, p. 377-384.

Paproth, E., Dusar, M., Bless, M. J. M., Bouckaert, J., Delmer, A., Fairon-Demaret, M., Houlleberghs, E., Laloux, M., Pierart, P., Somers, Y., Streel, M., Thorez, J., and Tricot, J., 1983, Bio- and lithostratigraphic subdivisions of the Silesian in Belgium, a review: Annals de la Société Geologique de Belgique, v. 106, p. 241-283.

Pearson, D. L., 1975, Palynology of the middle and upper Seminole coals (Pennsylvanian) of Tulsa County, Oklahoma: M.S. thesis, University of Oklahoma, Norman, 72 p.

Peppers, R. A., 1979, Development of coal-forming floras during the early part of the Pennsylvanian in the Illinois basin; in, Depositional and Structural History of the Pennsylvanian System of the Illinois Basin—Field Trip 9, Part 2, Invited Papers, J. E. Palmer and R. R. Dutcher, eds.: Ninth International Congress on Carboniferous Stratigraphy and Geology, Illinois State Geological Survey, Guidebook Series 15a, p. 8-14.

Peppers, R. A., 1984, Comparison of miospore assemblages in the Pennsylvanian System of the Illinois basin with those in the Upper Carboniferous of western Europe; in, Biostratigraphy, P. K. Sutherland and W. L. Manger, eds.: Compte Rendu, Neuvième Congrès. International de Stratigraphie et de Géologie du Carbonifère, Washington and Champaign-Urbana, 1979, v. 2, p. 483-502.

Peppers, R. A., 1996, Palynological correlation of major Pennsylvanian (Middle and Upper Carbonaceous) chronostratigraphic boundaries in the Illinois and other coal basins: Geological Society of America, Memoir 188, 113 p.

Peppers, R. A., and Brady, L. L., 1997, Palynological correlation of Atokan and lower Desmoinesian (Pennsylvanian) strata between the Illinois basin and eastern Kansas: Geological Society of America, Abstracts with Programs, v. 29, no. 4, p. 65.

Peppers, R. A., Howe, W. B., and Deason, K., 1993, Palynological zonation and physical stratigraphy of pre-Desmoinesian strata along a subsurface cross section in northwestern Missouri: Geological Society of America, Annual Meeting of North-central Section, Abstracts with Program, v. 25, p. 72.

Phillips, T. L., and Peppers, R. A., 1984, Changing patterns of Pennsylvanian coal-swamp vegetation and implications of climatic control on coal occurrence: International Journal of Coal Geology, v. 3, p. 205-255.

Phillips, T. L., Peppers, R. A., and DiMichele, W. A., 1985, Stratigraphic and interregional changes in Pennsylvanian coal-swamp vegetation-environmental inferences; in, Paleoclimatic Controls on Coal Resources of the Pennsylvanian System of North America, 
T. L. Phillips and C. B. Cecil, eds.: International Journal of Coal Geology, v. 5, p. 43-110.

Pierce, W. G., and Courtier, W. H., 1937, Geology and coal resources of the southeastern Kansas coal field in Crawford, Cherokee, and Labette counties: Kansas Geological Survey, Bulletin 24, 122 p.

Rashid, M. A., 1968, Palynology of the Bostwick Member of the Lake Murray Formation (Pennsylvanian) of southern Oklahoma: M.S. thesis, University of Oklahoma, Norman, 122 p.

Ravn, R. L., 1979, An introduction to the stratigraphic palynology of the Cherokee Group (Pennsylvanian) coals of Iowa: Iowa Geological Survey, Technical Paper 6, 117 p.

Ravn, R. L., 1986, Palynostratigraphy of the Lower and Middle Pennsylvanian coals of Iowa: Iowa Geological Survey, Technical Paper 7, 245 p.

Ravn, R. L., and Fitzgerald, D. J., 1982, A Morrowan (Upper Carboniferous) miospore flora from eastern Iowa, U.S.A.: Paleontology, Abt. B., v. 183, p. 106-172.

Ravn, R. L., Swade, J. W., Howes, M. R., Gregory, J. L., Anderson, R. R., and Van Dorpe, P. E., 1984, Stratigraphy of the Cherokee Group and revision of Pennsylvanian stgratigraphic nomenclature in Iowa: Iowa Geological Survey, Technical Information Series 12, 76 p.

Rosowitz, D. W., 1982, Palynology and paleoecology of the Riverton coal bed (Desmoinesian, Pennsylvanian) in southeastern Kansas: M.S. thesis, Wichita State University, Wichita, Kansas, 136 p.

Ruffin, J. H., 1961, Palynology of the Tebo coal (Pennsylvanian) of Oklahoma: M.S. thesis, University of Oklahoma, Norman, 124 p.

Searight, W. V., 1955, Field trip guidebook, Second Annual Meeting of Association of Missouri Geologists: Missouri Geological Survey and Water Resources, Report of Investigations 20, 44 p.

Searight, W. V., 1959, Pre-Marmaton Pennsylvanian deposits of the Forest City basin, Missouri: Geological Society of America, Abstracts with Program, Bulletin 20, p. 1,673.

Searight, W. V., and Howe, W. B., 1961, Pennsylvanian System; in, The Stratigraphic Succession in Missouri, J. W. Koenig, ed.: Missouri Division of Geological Survey and Water Resources, Second Series, v. 40, p. 78-122.

Searight, W. V., et al., 1953, Classification of the Desmoinesian (Pennsylvanian) of the northern midcontinent: American Association Petroleum Geologists, Bulletin, v. 37, p. 2,747-2,749.

Simpson, H. M., 1969, Palynology and the vertical sedimentary profile of Missourian strata, Tulsa County, Oklahoma: M.S. thesis, University of Tulsa, Tulsa, Oklahoma, 73 p.

Smith, A. H. V., and Butterworth, M. S., 1967, Microspores in the coal seams of the Carboniferous of Great Britain: Paleontological Association, Special Paper 1, 324 p.

Spivey, R. C., and Roberts, T. G., 1946, Lower Pennsylvanian terminology in central Texas: American Association of Petroleum Geologists, v. 30, p. 181-186.

Stewart, G. F., 1975, Kansas; in, Introduction and Regional Analyses of the Pennsylvanian System, Pt. 1 of Paleotectonic Investigations of the Pennsylvanian System in the United States, E. D. McKee and E. J. Crosby, coords.: U.S. Geological Survey, Professional Paper 853, p. 127-156.

Suneson, N. H., and Hemish, L. A., eds., 1994, Geology and resources of the eastern Ouachita Mountains Frontal Belt and southeastern Arkoma basin, Oklahoma: Oklahoma Geological Survey, Guidebook 29, 294 p.

Thompson, M. L., 1953, Primative Fusulinella from southern Missouri: Journal of Paleontology, v. 27, p. 321-327.

Thompson, T. L., 1979, The Mississippian and Pennsylvanian (Carboniferous) Systems in the United States-Missouri: U.S. Geological Survey, Professional Paper 1110-N, 22 p.

Urban, J. B., 1962, Palynology of the Mineral coal (Pennsylvanian) of Oklahoma and Kansas: M.S. thesis, University of Oklahoma, Norman, 146 p.
Urban, L. L., 1965,Palynology of the Drywood and Bluejacket coals (Pennsylvanian) of Oklahoma: M.S. thesis, University of Oklahoma, Norman, 91 p.

Wanless, H. R., 1956, Classification of the Pennsylvanian rocks of Illinois as of 1956: Illinois State Geological Survey, Circular 217, $14 \mathrm{p}$.

Wilson, L. R., 1958, Photographic illustrations of fossil spore types from Iowa: Oklahoma Geological Survey, Oklahoma Geology Notes, v. 18, p. 99-101.

Wilson, L. R., 1964, Palynological assemblage resemblance in the Croweburg coal of Oklahoma: Oklahoma Geology Notes, v. 24, p. 138-143.

Wilson, L. R., 1965, Palynological age determination of a rock section in Ti Valley, Pittsburg County, Oklahoma: Oklahoma Geology Notes, v. 25, p. 11-18.

Wilson, L. R., 1970, Palynology of Oklahoma's ten-foot coal seam: Oklahoma Geology Notes, v. 30, p. 62-63.

Wilson, L. R., 1976a, Desmoinesian coal seams of northeastern Oklahoma and their palynological content: Tulsa Geological Society Field Trip Guidebook, p. 19-32.

Wilson, L. R., 1976b, A preliminary assessment of palynomorph stratigraphy in Morrowan and Atoka rocks of the Ouachita Mountains, Oklahoma-A study of Paleozoic rocks in Arbuckle and eastern Ouachita Mountains of southern Oklahoma: Gulf Coast Association of Geological Societies, Field Trip Guidebook, p. 83-89.

Wilson, L. R., 1979a, Palynological evidence for age assignment of basal Cherokee (Pennsylvanian) strata in southeastern KansasSymposium on Evolutionary Botany and Biostratigraphy, University of Calcutta, India, February, 1979: Oklahoma Geology Notes, v. 39, p. 76-79.

Wilson, L. R., 1979b. Palynological and plant compression evidence for a Desmoinesian-Missourian (Pennsylvanian) Series boundary in northeastern Oklahoma: Abstracts, Ninth International Congress on Carboniferous Stratigraphy and Geology, Urbana, Illinois, p. 234-235.

Wilson, L. R., 1984, Evidence for a new Desmoinesian-Missourian boundary (Middle Pennsylvanian) in Tulsa County, Oklahoma, U.S.A.; in, A. K. Ghosh Commemorative Volume, A. K. Sharma, G. C. Mitra, and M. Banerjee, eds.: Today and Tomorrow Printers and Publishers, New Delhi, p. 251-265.

Wilson, L. R., and Bennison, A. P., 1981, Multidiscipline evidence for a new Desmoinesian-Missourian (Pennsylvanian) boundary in central Oklahoma: Palynology, v. 5, p 244-245.

Wilson, L. R., and Coe, E. A., 1940, Description of some unassigned plant microfossils from the Des Moines Series of Iowa: American Midland Naturalist, v. 23, p. 182-186.

Wilson, L. R., and Hoffmeister, W. S., 1956, Plant microfossils of the Croweburg coal: Oklahoma Geological Survey, Circular 32, 57 p.

Wilson, L. R., and Hoffmeister, W. S., 1958, Plant microfossils in the Cabaniss coals of Oklahoma and Kansas: Oklahoma Geology Notes, v. 18, p. 27-30.

Wilson, L. R., and Kosanke, R. M., 1944, Seven new species of unassigned plant microfossils from the Des Moines series of Iowa: Proceedings Iowa Academy of Science, v. 51, p. 329-332.

Wilson, L. R., and Rashid, M. A., 1982, Paleobotanical evidence for an age assignment of the Bostwick Member (Pennsylvanian): Abstracts with Program, Geological Society of America, South-Central Section, Norman, Oklahoma, v. 14, p. 140.

Wright, C. R., 1975, Environments within a typical Pennsylvanian cyclothem; in, Paleotectonic Investigations of the Pennsylvanian System in the United States, Part II-Interpretative Summary and Special Features of the Pennsylvanian System, McKee and others, eds.: U.S. Geological Survey, Professional Paper 853, p. 73-84. 